\title{
Nam Lot (MIS 5) and Duoi U'Oi (MIS 4) Southeast Asian sites revisited: Zooarchaeological and isotopic evidences
}

Anne-Marie Bacon ${ }^{\mathrm{a}}$, Nicolas Bourgon ${ }^{\mathrm{b} 1}$, Elise Dufour ${ }^{\mathrm{b}}$, Clément Zanolli ${ }^{\mathrm{c}}$, Philippe Duringer ${ }^{\mathrm{d}}$, Jean-Luc Ponche ${ }^{\mathrm{e}}$, Pierre-Olivier Antoine ${ }^{\mathrm{f}}$, Laura Shackelford ${ }^{\mathrm{g}}$, Nguyen Thi Mai Huong ${ }^{\mathrm{h}}$, Thongsa Sayavonkhamdy ${ }^{\mathrm{i}}$, Elise, Patole-Edoumba ${ }^{\mathrm{j}}$, FabriceDemeter ${ }^{\mathrm{kl}}$

${ }^{a}$ AMIS Anthropologie moléculaire et imagerie de synthèse, UMR 5288 CNRS, Université Paris Descartes, Faculté de chirurgie dentaire, 1 rue Maurice Arnoux, 92120 Montrouge, France ${ }^{\mathrm{b}}$ Archéozoologie, Archéobotanique: Sociétés, pratiques et environnements, UMR 7209, Sorbonne Universités, Muséum national d'Histoire naturelle, CNRS, CP55, 55 rue Buffon, 75005 Paris, France

${ }^{c}$ AMIS Anthropologie moléculaire et imagerie de synthèse, UMR 5288 CNRS, Université Toulouse III - Paul Sabatier, 118 Route de Narbonne, 31062 Toulouse Cedex 9, France

${ }^{\mathrm{d}}$ Ecole et Observatoire des Sciences de la Terre (EOST), Institut de Physique du Globe de Strasbourg (IPGS), UMR 7516 CNRS, Université de Strasbourg, 1 rue Blessig, 67084 Strasbourg Cedex, France

${ }^{\mathrm{e}}$ Laboratoire Image Ville et Environnement, UMR 7362, Institut de Géologie, 1 rue Blessig, 67084 Strasbourg Cedex, France

${ }^{\mathrm{f}}$ Institut des Sciences de l'Évolution, CC64, Université de Montpellier, CNRS, IRD, EPHE, Place Eugène Bataillon, 34095 Montpellier, France

${ }^{g}$ Department of Anthropology, University of Illinois at Urbana-Champaign, Urbana, IL 61801, USA

${ }^{\mathrm{h}}$ Anthropological and Palaeoenvironmental Department, Institute of Archaeology, 61 Phan Chu Trinh, Hanoi, Viet Nam

${ }^{\text {I }}$ Department of National Heritage, Ministry of Information and Culture, PO Box 122, Vientiane, Laos

${ }^{\mathrm{j}}$ Muséum d'histoire naturelle, 28 rue Albert Ier, 17000 La Rochelle, France

${ }^{\mathrm{k}}$ Center for GeoGenetics, Øster Voldgade 5-7, 1350 Copenhagen K, Denmark

${ }^{1}$ Musée de l'Homme, UMR 7206, 17 Place du Trocadéro, 75116 Paris, France

\begin{abstract}
The Nam Lot site in Laos and the hominin-bearing Duoi U'Oi site in Vietnam are dated to MIS 5 (86-72 ka) and MIS $4(70-60 \mathrm{ka})$, respectively. Located in the same latitudinal belt $\sim 20^{\circ} \mathrm{N}$ in the north of the Indochinese area, the faunal assemblages recovered from breccia deposits in a karstic context have the potential to provide information on the palaeoenvironmental conditions faced by earliest modern humans when they entered the Southeast Asian mainland. Here, zooarchaeological evidence of faunas are reviewed combined with a new stable isotope analysis $\left(\delta^{13} \mathrm{C}\right.$ and $\left.\delta^{18} \mathrm{O}\right)$ of tooth enamel of mammals from Nam Lot (86-72 ka), to explore environmental conditions during MIS 5-4 periods.

In both sites, large predators (hyena, tiger, leopard, and dhole) had access to a great diversity of prey among mammals. The Nam Lot isotopic results indicate during MIS 5 a complexity in the forest habitats with closed low-light tropical rainforest, "intermediate" rainforest, and $\mathrm{C}_{3}-\mathrm{C}_{4}$ open woodland/'savanna'. This woodland ecosystem - notably the "intermediate" rainforest - carried most of the ungulate biomass, with a variety of small to large-bodied ground-dwelling animals.
\end{abstract}

Keywords: Mammalian faunas, Vietnam, Laos, MIS 5-4, Palaeoenvironment, Hominins 


\section{Introduction}

The debate surrounding the timing of early modern Homo sapiens arrival in Southeast Asia has shifted recently to the time range of $\sim 120-70$ thousand years ago [ka] in Marine Isotope Stage [MIS] 5 (Reyes-Centeno, 2016; Bae et al., 2017; Rabett, 2018). Indeed, archaeological and fossil data show that there is little doubt today that humans expanded from Africa towards Asia during the earliest stages of MIS 5, through the Arabian Peninsula to Southeast Asia, and adapting to various habitats along multiple routes, including inland vegetation corridors, coastal routes and riverine corridors (Field and Lahr, 2005; Mellars, 2006a, Mellars, 2006b; Mellars et al., 2013; Field et al., 2007; Armitage et al., 2011; Oppenheimer, 2012; Boivin et al., 2013; Reyes-Centeno, 2016; Corny et al., 2017; Bae et al., 2017; Rabett, 2018). If the apparently concomitant arrival of Homo sapiens associated with a modern fauna around $120 \mathrm{ka}$ at Punung in Java needs to be verified (Storm et al., 2005; Storm and de Vos, 2006; Westaway et al., 2007), other data from southern China (Zhiren, 116-106 ka, Liu et al., 2010a; Cai et al., 2017; Huanglong, 100-80 ka, Liu et al., 2010b; Shen et al., 2013; Luna, 126.9-70.2 ka, Bae et al., 2014; Longtanshan, >83$60 \mathrm{ka}$, Curnoe et al., 2016) witness the presence of anatomically modern humans and other forms described as transitional in this time interval, whereas the Fuyan fossils (120-80 ka, Liu et al., 2015) appear highly controversial (Michel et al., 2016). In relation to MIS 4 (Periglacial Stage, 71-52 ka), evidence come from the recently reconsidered age of the Lida Ajer site in Sumatra with one clearly identified Homo sapiens tooth (73-63 ka, Westaway et al., 2017), combined with the newly recovered Homo sapiens at Tam Pà Ling [TPL] from northeastern Laos $~ 70$ ka (Demeter et al., 2017; Shackelford et al., 2018). By 65 ka, modern humans had already reached northern Australia (Clarkson et al., 2017). While we are not sure if archaic hominins were present in mainland SE Asia until the appearance of modern humans, archaic populations either related to Homo erectus or to a still unknown early Homo ancestor appear to be present in Java (Yokoyama et al., 2008; Indriati et al., 2011), in Flores (Sutikna et al., 2016), and maybe in the Philippines (Mijares et al., 2010) until c. 100 to $50 \mathrm{ka}$.

Determining the palaeoenvironmental conditions that the earliest modern humans faced when they entered the Southeast Asian mainland around the MIS 5-4 transition is an important issue that has been for the moment only poorly addressed. Human and large mammalian fossils we discovered in the north of Indochina come from various depositional contexts in tropical karst sites. In northern Vietnam and Laos, the only available MIS 5 data for reconstructing the habitats based on large mammals were derived from breccia deposits. Two sites located at the foot of the Pà Hang Mountain have yielded faunal assemblages, Tam Hang South (92-60 ka; Bacon et al., 
2008a, Bacon et al., 2011, Bacon et al., 2015) and Nam Lot (86-72 ka; Bacon et al., 2012, Bacon et al., 2015). In relation to MIS 4, findings come from clay layers that filled the TPL cave, located at the summit of the same Pà Hang Mountain. The stratigraphic sequence of TPL reveals, in itself, the possibility of different human populations arriving during MIS 4-3. The youngest remains at $46 \pm 4 \mathrm{ka}$ (OSL) consist of the TPL1 cranium with fully modern traits and the TPL2 mandible with a mixture of modern and archaic traits (Demeter et al., 2012, Demeter et al., 2015). Recently, a new fossil, a partial mandible (TPL3) and a rib (TPL4), has been added to these discoveries, pushing the occupation of the site back to $70 \pm 8 \mathrm{ka}$ (IRSL) (Shackelford et al., 2018). This latter fossil is a reliable indicator that modern Homo sapiens occupied inland sites $\sim 70 \mathrm{ka}$, but there is no direct faunal evidence - only a handful of isolated teeth of large mammals - associated with the human remains at the site. In contrast, we found a rich mammalian fauna in breccia deposits from a contemporaneous site, Duoi U'Oi in northern Vietnam (70-60 ka; Bacon et al., 2008b, Bacon et al., 2015), located 100 km apart from Pà Hang.

With the current state of knowledge, available data provide a generalized overview of the ecosystems of Indochina. On a continental scale, at the latitudes $\sim 20^{\circ} \mathrm{N}$, sedimentological and palynological records of the Leizhou Peninsula (Zheng and Lei, 1999), showed that the MIS 5 period $(\sim 128-71 \mathrm{ka})$ was marked by a warm climate, with temperatures $\sim 2{ }^{\circ} \mathrm{C}$ warmer than during the Holocene and a vegetation cover dominated by a fagaceous monsoon evergreen forest. The shift from MIS 5 to MIS 4 was characterized by the increase of temperate elements (the monsoon forest was replaced by high-elevation vegetation; the montane forest reached down to the lowland by at least $600 \mathrm{~m}$ ), under cool and relatively wet conditions (with $\sim 4{ }^{\circ} \mathrm{C}$ cooler temperatures than present). At that time, the continent was inhabited by diversified faunas with terrestrial, semi-arboreal and arboreal species. The structure of these tropical forest ecosystems was particularly shaped by the presence of numerous large-sized herbivores $>250 \mathrm{~kg}$ (bovid, rhinoceros, and tapir), and very large-sized herbivores (megaherbivores $>1000 \mathrm{~kg}$ up to $5000 \mathrm{~kg}$, Owen-Smith, 1988) (Stegodon, elephant, and giant tapir) (Wang et al., 2007; Rink et al., 2008; Bacon et al., 2018).

On a regional scale, palaeoenvironmental data need to be specified. In northeastern Laos (TPL, Tam Hang and Nam Lot), the nature of the forest cover is still unknown, while palynological results from northern Vietnam (Duoi U'Oi) provided sporadic data (Bacon et al., 2008b). The impacts of climate change at the MIS 5-4 transition on the biodiversity of megaherbivore-bearing ecosystems, and on the distribution and structure of the vegetation, remain to be assessed. 
Beyond the scarcity of evidence in the Southeast Asian mainland, another major constraint for analyzing the evolution of hominins and their habitats is the representation of remains and their state of preservation which make the identification of hominin species difficult (Demeter et al., 2004, Demeter et al., 2005; Liu et al., 2010b; Bae et al., 2014; Curnoe et al., 2016). Nam Lot (86$72 \mathrm{ka}$ ) has provided one isolated incisor assigned to a hominin (Homo sp.), but the possibility that it may belong to Pongo could not be fully ruled out either. Duoi U'Oi (70-60 ka) has provided two isolated molars assigned more securely to an unidentified hominin (Homo sp.) (Bacon et al., 2008b).

In this issue, stable isotope analysis is used increasingly to gain insights into past and present environments and animal ecology. $\delta^{13} \mathrm{C}$ values of mammal tissues reflect the isotopic composition of ingested and assimilated food and can furthermore be used to reveal characteristics of ecology and environment (DeNiro and Epstein, 1978; Lee-Thorp et al., 1989; Ambrose and Norr, 1993; Cerling and Harris, 1999; Kohn and Cerling, 2002; Sponheimer et al., 2003; Passey et al., 2005). Consequently, plants' isotopic composition is reflected in every consumer's values - even carnivores' - since they constitute the primary sources of carbon in food webs. In tropical and subtropical regions, the flora is composed of plants using $\mathrm{C}_{3}$ and $\mathrm{C}_{4}$ photosynthetic pathways (Still et al., 2003), which $\delta^{13} \mathrm{C}$ values vary markedly (Smith and Epstein, 1971). While $\mathrm{C}_{3}$ plants dominate the terrestrial vegetation biomass (Still et al., 2003), including that of tropical forests (Ehleringer and Monson, 1993), C4 plants are mostly restricted to tropical and subtropical regions as they require considerable levels of light and high temperature during their growing season (Ehleringer and Monson, 1993; Tieszen et al., 1997; Sage et al., 1999; Still et al., 2003). In the context of tropical forest, these distinctions have been used in Africa (e.g., White et al., 2009; Lee-Thorp et al., 2010; Sponheimer et al., 2013; Levin et al., 2015) and South Asia (e.g., Krigbaum, 2003, Krigbaum, 2005; Roberts et al., 2015, Roberts et al., 2017a) to assess the degrees of faunal and human reliance on forest resources dominated by $\mathrm{C}_{3}$ plant taxa as opposed to open habitats where both $\mathrm{C}_{3}$ and $\mathrm{C}_{4}$ plant resources are available. Moreover, more subtle distinction in $\delta^{13} \mathrm{C}$ of carbon sources linked to the "canopy effect" also exists within tropical $C_{3}$ forest ecosystems (van der Merwe and Medina, 1991). In Asia, the combined analysis of oxygen and carbon stable isotopes provided direct evidence of human rainforest adaptation from the Late Pleistocene to the Neolithic (Krigbaum, 2003, Krigbaum, 2005; Roberts et al., 2015, Roberts et al., 2017a). $\delta^{18} \mathrm{O}$ measured in tooth enamel mostly reflects the isotope composition of ingested water (drinking and food) (Longinelli, 1984; Luz et al., 1984; Bryant and Froelich, 1995). In plants, $\delta^{18} \mathrm{O}$ is related to soil water absorbed, which in turn derives 
from meteoric water that varies primarily according to the latitude and climate (Dansgaard, 1964; Longinelli, 1984). Within tropical and subtropical regions, $\delta^{18} \mathrm{O}$ values can also be used, along with $\delta^{13} \mathrm{C}$ values, to infer canopy density in a forest environment (Buchmann et al., 1997; Buchmann and Ehleringer, 1998).

In this paper, we focus the analysis on the two sites: Nam Lot (MIS 5: 86-72 ka) and Duoi U'Oi (MIS 4: 70-60 ka) located in the same latitudinal belt $\sim 20^{\circ} \mathrm{N}$. First, zooarchaeological evidences are reviewed to estimate the diversity of potential resources exploitable by predators (carnivores and/or hominins) among ground-dwelling, semi-arboreal, and arboreal mammals. These approaches were combined with a new stable isotope analysis $\left(\delta^{13} \mathrm{C}\right.$ and $\left.\delta^{18} \mathrm{O}\right)$ of tooth enamel of mammals from Nam Lot (86-72 ka) for which the material was available for sampling. $\delta^{18} \mathrm{O}$ values are used to provide additional palaeoecological information related to $\delta^{13} \mathrm{C}$ values.

\section{Materials and methods}

2.1. Presentation of the sites and mammalian assemblages

Nam Lot is an upland site located along the basal part of the Pà Hang Mountain at an elevation of $1120 \mathrm{~m}$ in northeastern Laos, Hua Pan province (Arambourg and Fromaget, 1938; Fromaget, 1940a, Fromaget, 1940b) (Fig. 1, Fig. 2). We discovered in the Nam Lot cave an assemblage of 385 isolated teeth (NISP) of mammals during the field season of 2007 (Duringer et al., 2012) (Fig. 3, Table 1SI). The majority of remains were derived from the breccia and from the silty to sandy clays in the lower part of the cave, which has an estimated age range of 86-72 ka (OSL and U-series; Bacon et al., 2015). 


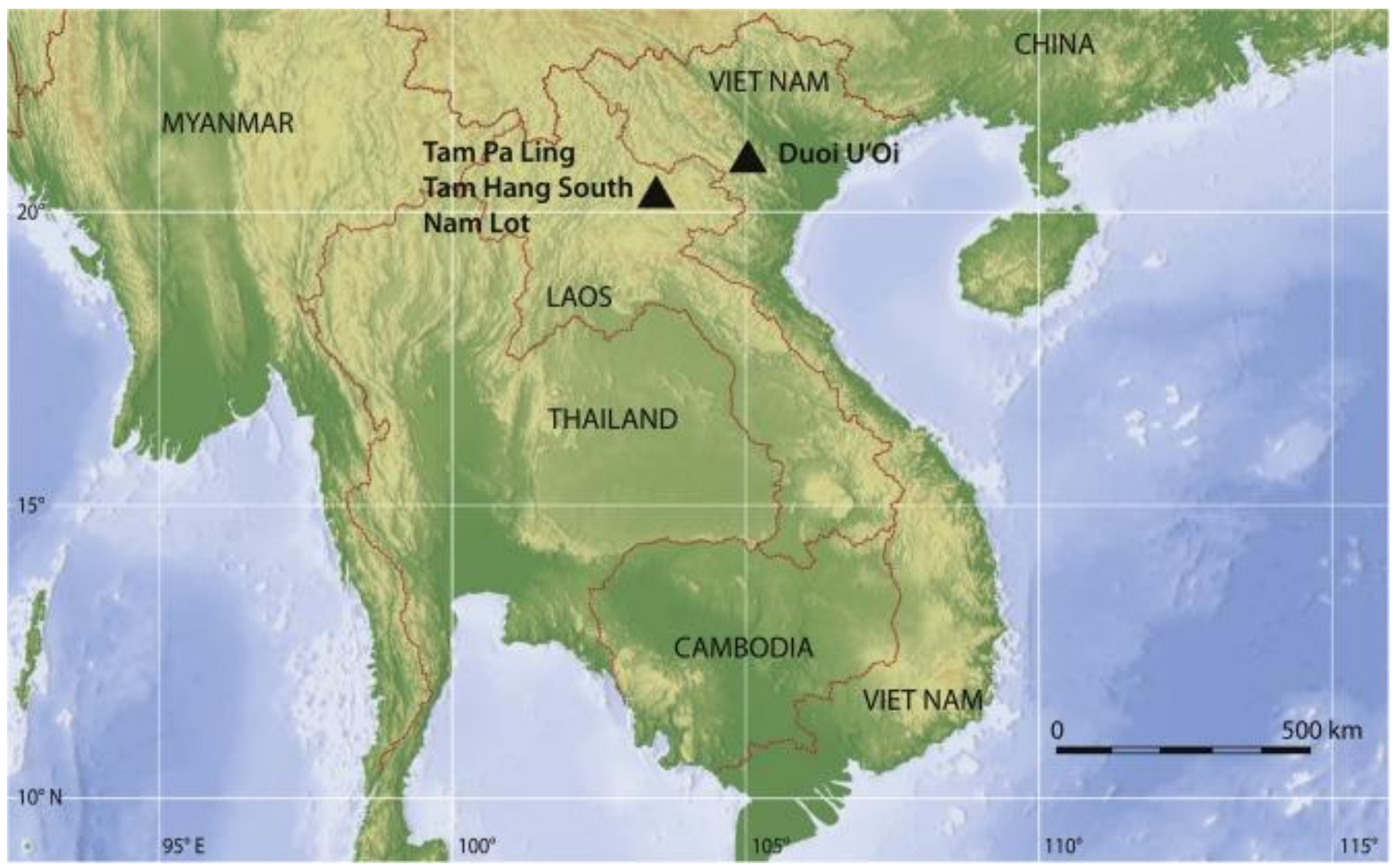

Fig. 1. Map of the Southeast Asian mainland with the location of the studied Laotian and Vietnamese sites indicated by the black triangles.

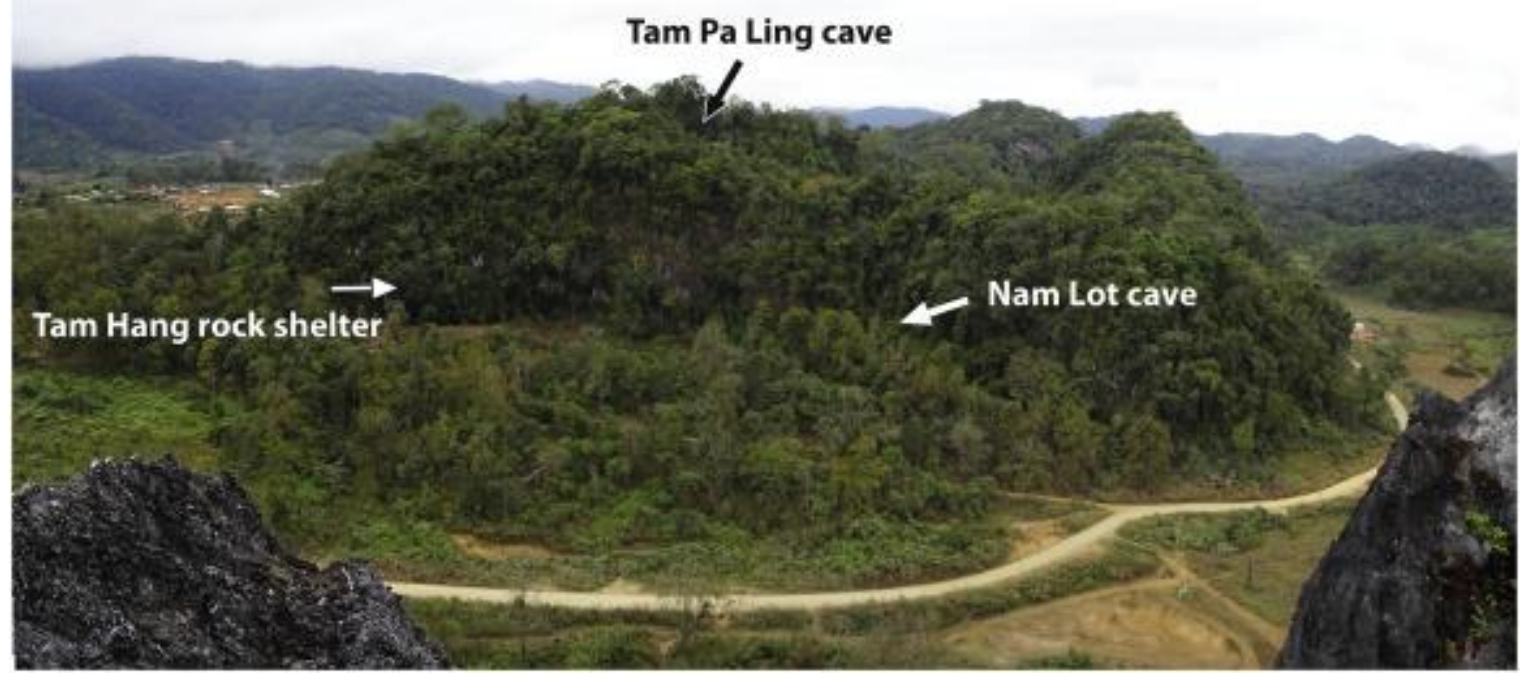

Fig. 2. Photo of the Pà Hang Mountain in northeastern Laos. 


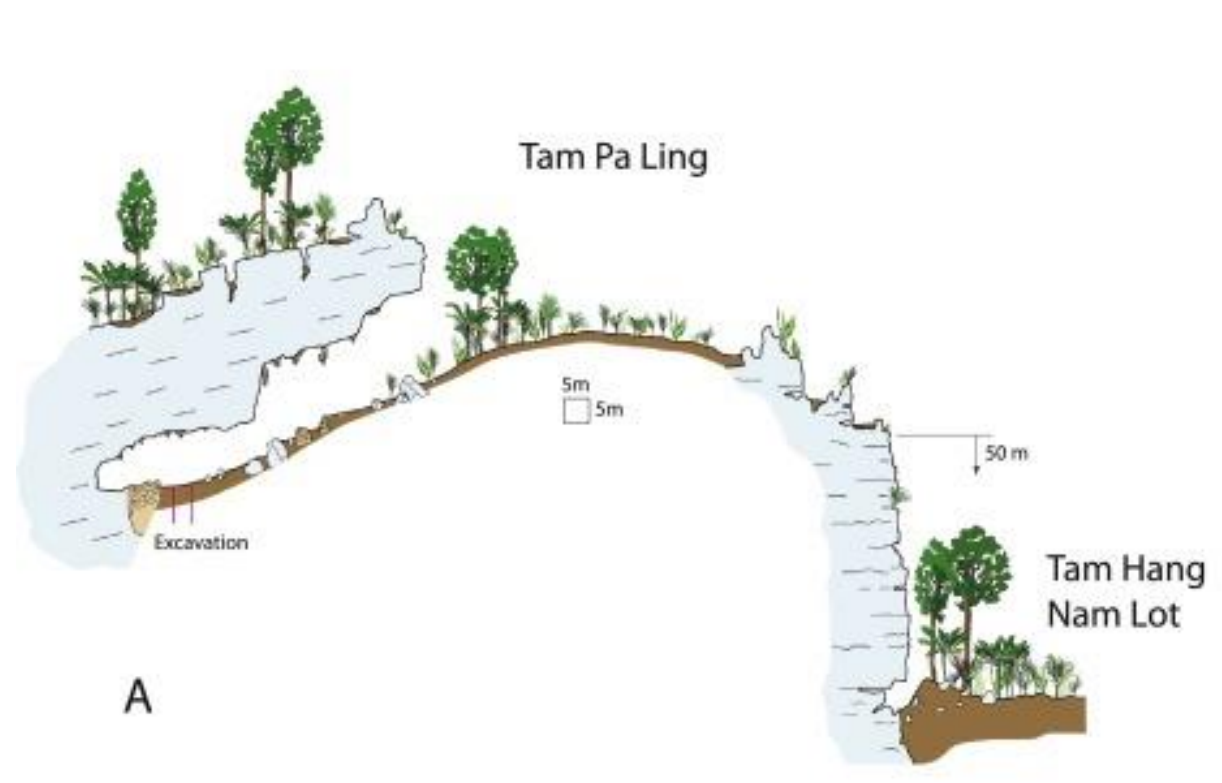

B

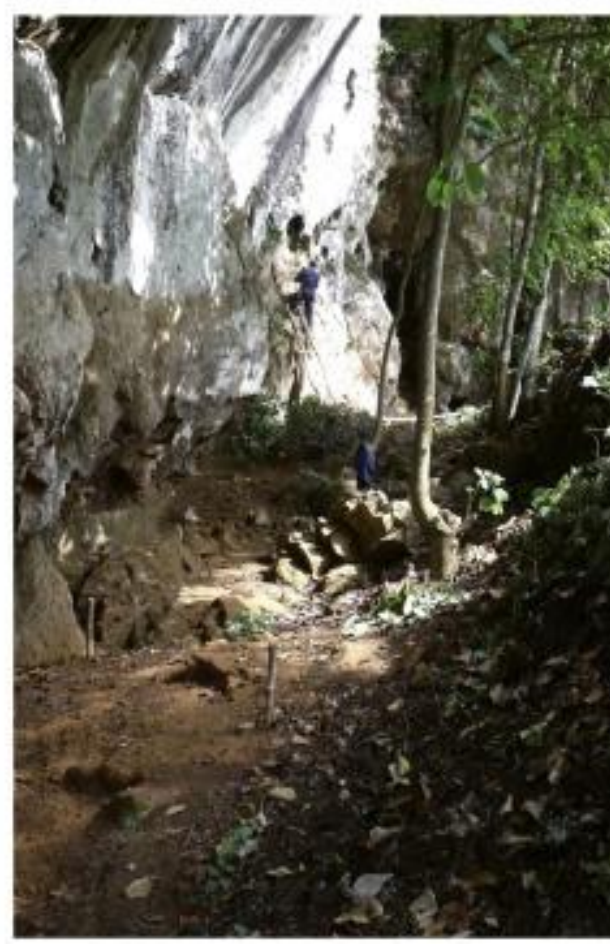

Fig. 3. A. Section of the Pà Hang Mountain showing the location of the different localities. The fossil-bearing site includes various depositional contexts: the silty to sandy clay layers of the Tam Pà Ling cave at an elevation of $1170 \mathrm{~m}$, and the breccia deposits of the Nam Lot cave and Tam Hang South rock shelter located along the cliff of the Mountain at an elevation of 1120 m; B. Photo of the basal part of the Pà Hang cliff.

The Nam Lot fauna is composed of middle- to large-sized mammals (Artiodactyla, Perissodactyla, Proboscidea, Carnivora, Primates, and large Rodentia), whereas the whole category of small mammals and microvertebrates are lacking due to postburial processes in the karsts (Bacon et al., 2015). Compared to the species diversity in living faunas from regions situated at the same northern latitudes $\left(0^{\circ}-25^{\circ}\right)$ (Corbet and Hill, 1992), Artiodactyla (five identified species among seven taxa) show remarkable similarities, whereas Perissodactyla and Proboscidea (six identified taxa at the species and genus level) show a number of species twice greater. The diversity in Carnivora species is largely underestimated - eight well-identified species are recorded at Nam Lot - considering the 21 to 29 species inventoried in the living faunas in the northern latitudes. In relation to small-sized Primates, the assessment of species diversity remains limited due to the fact that most identifications could only be made at the genus level (Bacon et al., 2015). 
The Duoi U'Oi lowland site, located around 100 km away from the Pà Hang Mountain (Fig. 1), yielded an assemblage of 871 isolated teeth (NISP) of mammals (Table 1SI). The cave is situated around 3 to $5 \mathrm{~m}$ above the level of the alluvial plain and all teeth come from one well-preserved calcareous to argillaceous breccia located along the wall of the only excavated corridor (Fig. 4) (Bacon et al., 2008b). Considering the processes of transport through the cave system and the formation of the breccia, the fossiliferous layer formed within a relatively short time period during a unique depositional event (only one phase of stagnation with no reworking and redeposition). The estimated age of the fauna (70-60 ka) is based on luminescence dating of the underlying sandy and silty clay unit and U-series dating of the calcitic floor (66 $\pm 3 \mathrm{ka})$ that crosses the fossiliferous breccia (Bacon et al., 2015).

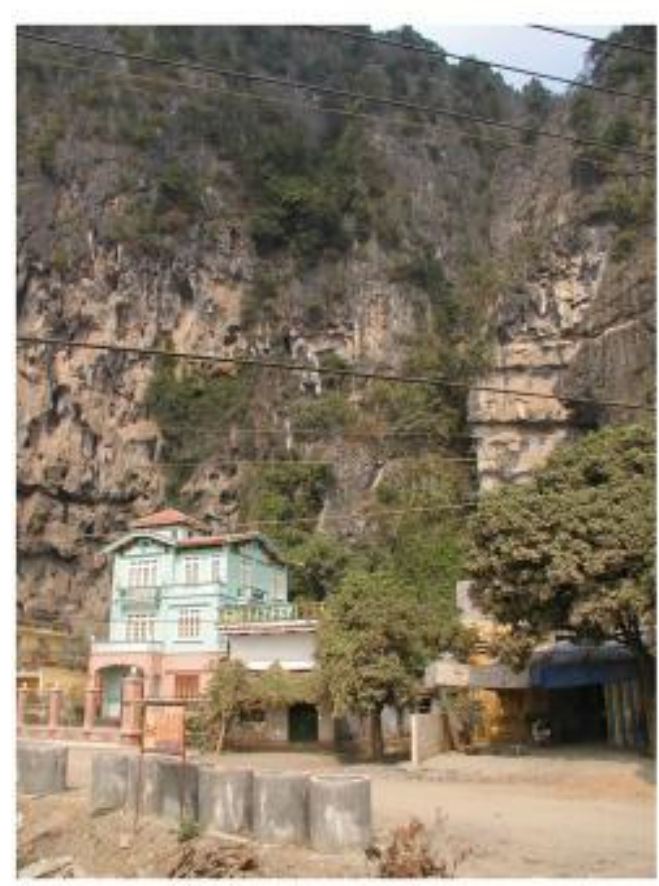

A

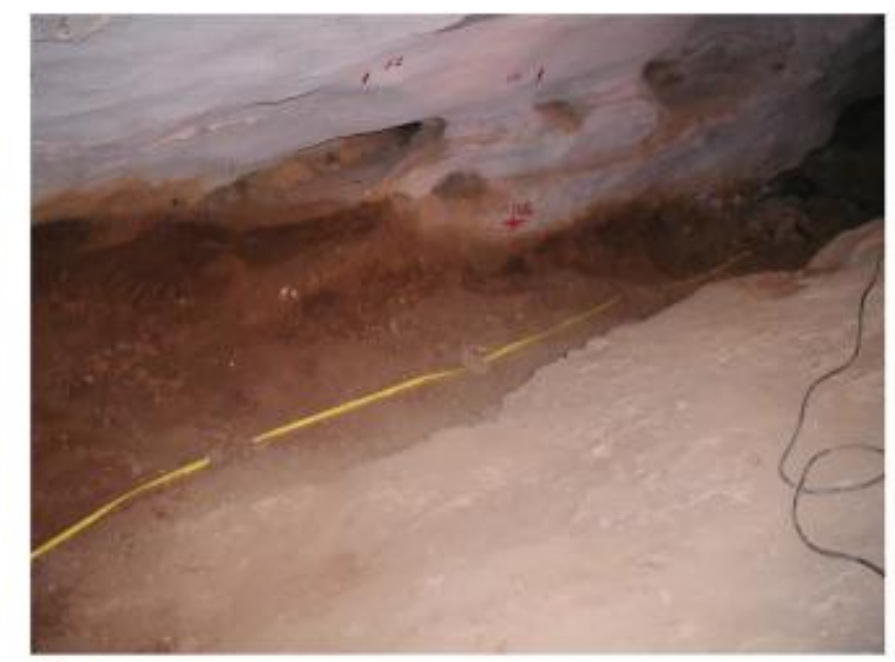

B

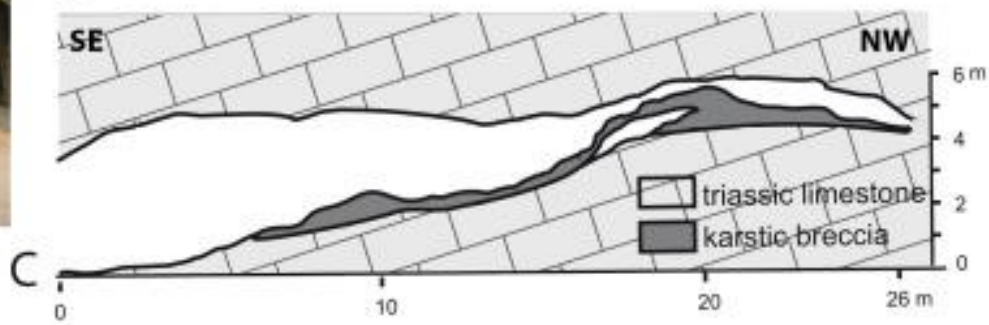

Fig. 4. Location and stratigraphic context of the Duoi U'Oi breccia deposits. A. The entrance of the cave is situated behind houses at the level of the alluvial plain ( $3 \mathrm{~m}$ above the alluvial plain); B. All teeth (fauna and hominins) come from one well-preserved calcareous to argillaceous breccia located along the wall of one corridor (corridor 1, Bacon et al., 2008b); C. Section of the corridor 1. 
In terms of preservation of remains, the Duoi U'Oi fauna is similar to that of Nam Lot with only middle- to large-sized mammals. In comparison with the species diversity in living faunas from the region (Corbet and Hill, 1992), Artiodactyla (six species) are well represented, whereas Perissodactyla and Proboscidea are much more numerous (seven taxa among which four identified species). In contrast, both the species diversity in Carnivora and Primates species are underestimated due to various biases (Bacon et al., 2015). At Duoi U'Oi, two Homo molars have been recognized by using dimensions and morphological criteria observed on the surface of crowns and roots (Bacon et al., 2008b). The teeth are heavily worn and it was impossible to assign them to any species (H. sapiens or H. erectus or another hominin) (Fig. 5).

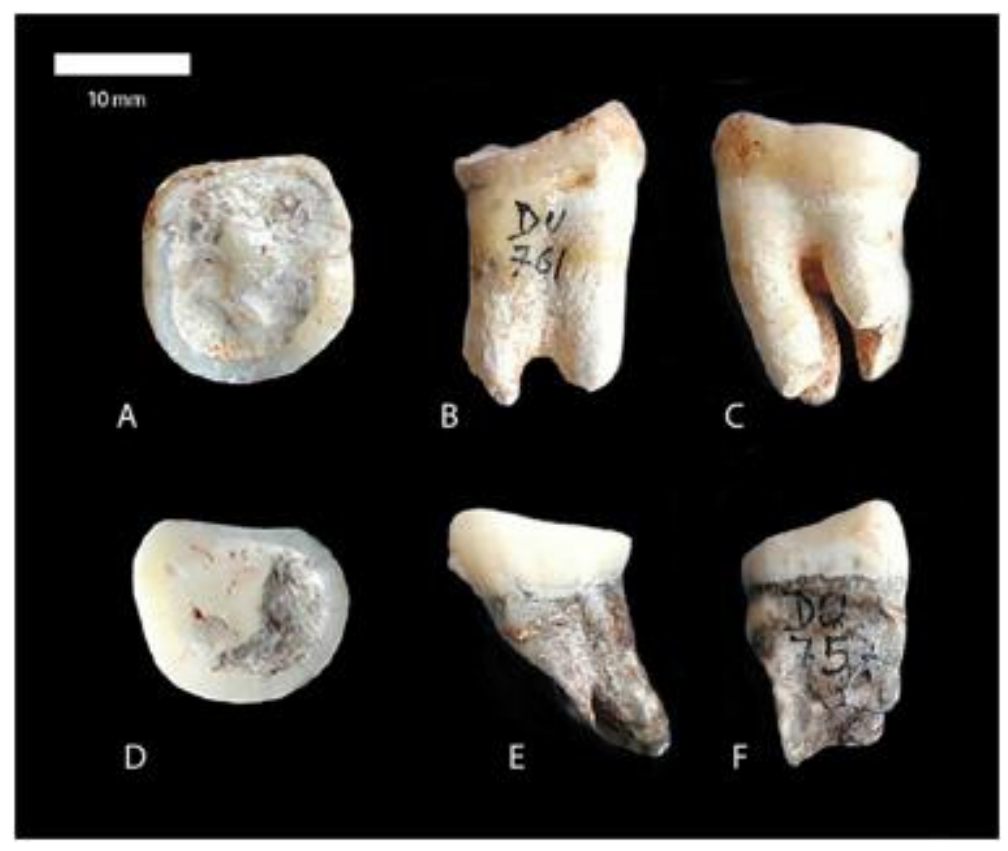

Fig. 5. The two hominin Duoi U'Oi teeth (70-60 ka, Vietnam). Contrary to the initial description (Bacon et al., 2008b), the DU761 specimen represents a mandibular molar and not a maxillary molar. Upper row: right lower m1 (DU761) in occlusal (A), buccal (B), and lingual (C) views; lower row: right upper M3 (DU757) in occlusal (D), buccal (E), and lingual views $(\mathrm{F})$.

Despite the poor preservation and rarity of pollen grains, the palynological analysis of the Duoi U'Oi sediments revealed a mixture of warm and temperate elements (Fig. 2SI). Of the components of the vegetation, $31 \%$ are pollen grains of non-arboreal plants and abundant Poacae, $25 \%$ are fern spores with diverse species, and $8 \%$ are arboreal and shrub plants. 
In both sites, the taphonomic analysis revealed that porcupines were the main accumulator agent before burial in the sediments (Bacon et al., 2015). The behavior of porcupines in accumulating a wide range of remains of predated or scavenged animals by either Carnivora or hominins, suggests that assemblages can be used as indicators of abundance of mammals living in the areas surrounding the sites, and therefore prey-preference by predators (Brain, 1981).

\subsection{Methods}

\subsubsection{Stable isotopic background}

The $\delta^{13} \mathrm{C}$ values in the bioapatite, which constitutes the bone and enamel of the tooth of a consumer, reflect those of its diet (DeNiro and Epstein, 1978; Lee-Thorp et al., 1989; Sponheimer and Lee-thorp, 1999; Cerling and Harris, 1999; Passey et al., 2005). Enamel is metabolically inert after formation. It thus only records the isotopic composition of the diet consumed during the period of its formation and maturation. It is not sensitive to post-mortem alteration and contamination and can thus be used to provide valid palaeodietary and palaeoenvironmental information (Lee-Thorp et al., 1989; Sponheimer and Lee-thorp, 1999; Cerling and Harris, 1999; Kohn and Cerling, 2002).

The basis for estimating the reliance on food resources is the existence of "isotopically" distinct and relatively invariant over time - resources in the environment, such as plants using $\mathrm{C}_{3}$ and $\mathrm{C}_{4}$ photosynthetic pathways (Smith and Epstein, 1971; O'Leary, 1981; Farquhar et al., 1989). C 3 plants dominate the terrestrial vegetation and are composed of trees, bushes, shrubs and grasses while $\mathrm{C}_{4}$ plants, mainly composed of grasses and sedges, occur primarily in the vast tropical and subtropical grassland and savanna regions as well as in temperate grassland regions in North and South America and Africa (Still et al., 2003). $\delta^{13} \mathrm{C}$ values range from $-37 \%$ o to $-20 \%$ with an average value of about $-27 \%$ for $\mathrm{C}_{3}$ plants (Kohn, 2010), and $-17 \%$ o to $-10 \%$ with an average value of about $-12.5 \%$ for $\mathrm{C}_{4}$ plants (Smith and Epstein, 1971; O'Leary, 1988). The range of $\delta^{13} \mathrm{C}$ values of $\mathrm{C}_{3}$ plants is large but extreme values are found in particular contexts. Values lower than $-31.5 \%$ are only found for vegetation growing under a heavy forest cover in tropics (Kohn, 2010), a phenomenon known as "canopy effect". These low $\delta^{13} \mathrm{C}$ values are caused by 1 ) decreasing light and photosynthetic rates, 2) increasing humidity and recycling of soil-respired $\mathrm{CO}_{2}$, both according to decreasing height from the forest crown (Vogel, 1978; Ehleringer et al., 1986, Ehleringer et al., 1987; Medina et al., 1986; Sternberg et al., 1989; van der Merwe and Medina, 1989; Graham et al., 2014). As a consequence, there is a trend in decreasing values with decreasing canopy height but this effect can be confounded by plant parts (Roberts et al., 2017b). 
A marked distinction in $\delta^{13} \mathrm{C}$ values can be nevertheless observed between vegetation from the densely forested areas and more open areas (e.g., Cerling et al., 2004, Cerling et al., 2015; Levin et al., 2008; Blumenthal et al., 2016; Roberts et al., 2015, Roberts et al., 2017a, Roberts et al., $2017 b$ ). Vegetation values higher than $-23 \%$ are only found in the Atacama Desert and for the Pinus genus in dry environments (Smith and Epstein, 1971; O'Leary, 1988; Ehleringer et al., 1998; Kohn, 2010). Therefore, a more restricted range of $\delta^{13} \mathrm{C}$ values of $-37 \%$ o to $-23 \%$ is considered for the studied geographic area.

Following the burning of fossil fuels over the past 150 years, the $\delta^{13} \mathrm{C}$ of atmospheric $\mathrm{CO}_{2}$ has decreased impacting the $\delta^{13} \mathrm{C}$ of all living organisms. The $\delta^{13} \mathrm{C}$ values of modern plants are then corrected ( $1.5 \%$; Friedli et al., 1986) when compared to those of organisms dating back from before the atmospheric $\mathrm{CO}_{2}$ shift. In the present study, the upper limit for $\mathrm{C}_{3}$ plants is thus shifted from $-23 \%$ to $-21.5 \%$, and the lower limit for $\mathrm{C}_{4}$ plants from $-17 \%$ o to $-15.5 \%$.

Distinct isotopic signatures are transmitted to the consumer with a trophic fractionation when the food's carbon is incorporated into the tissues of animals (Lee-Thorp et al., 1989). The value of the fractionation varies according to the tissue (bone collagen, enamel carbonate, hairs, etc.) and, for the same type of tissue, according to animal biology and digestive physiology (herbivorous, carnivorous, and omnivorous) (Lee-Thorp et al., 1989; Passey et al., 2005). We applied an average spacing of $+14 \%$ between diet and dental enamel bioapatite of herbivores (Lee-Thorp et al., 1989; Cerling and Harris, 1999; Passey et al., 2005). Although spacing range of $+12-14 \%$ is mentioned in the literature for ungulates (Lee-Thorp and van der Merwe, 1987), a more widespread spacing value of $\pm+14 \%$ o was considered more suitable in the present study (Cerling and Harris, 1999; Balasse, 2002; Passey et al., 2005). This choice is even more relevant considering that multiple diet-enamel spacing values were considered here, rather than a single one. Furthermore, as Nam Lot is located in low latitudes $\left(<40^{\circ} \mathrm{N}\right)$ within the tropics where herbaceous species are only of $\mathrm{C}_{4}$ photosynthetic type (Prentice et al., 1992; Still et al., 2003; Kohn and Cerling, 2002), it is possible to discriminate between "grazers" that mostly eat grass and low vegetation and "browsers" that preferentially eat leaves and soft shoots. An average enamel-diet spacing of $+9 \%$ was established for carnivores (Lee-Thorp et al., 1989). However, the $\delta^{13} \mathrm{C}$ values of dental enamel of carnivores are similar to those of their prey (LeeThorp et al., 1989) because the ingested and assimilated parts are soft tissues (muscles, fat, etc.) and not hard tissues. As such, a slightly negative value difference $(-1.3 \%$ ) was established between the $\delta^{13} \mathrm{C}$ values of dental enamel of the gray wolf (Canis lupus) and those of its prey (Fox-Dobbs et al., 2006). Although ursids are known to exhibit carnivore diet-enamel spacing 
(Bocherens, 2002; Bocherens et al., 2011), their dietary reliance however is not necessarily restricted to meat consumption.

An average enamel-diet spacing of omnivores (pigs and porcupines) of $+13 \%$ was established for pigs (Passey et al., 2005). Finally, the average enamel-diet spacing for primates is unclear and varies throughout the literature (e.g., Ambrose et al., 1997; Krigbaum, 2003; Cerling et al., 2004, Cerling et al., 2013; Codron et al., 2005; Sponheimer et al., 2013). Following current evidence (Cerling et al., 2004; Sponheimer et al., 2013), an average conservative enamel-diet spacing of $+13 \%$ has been used for primates for the present study.

The terms $\mathrm{C}_{3}$ and $\mathrm{C}_{4}$ refer to photosynthetic type plants and are adequate to describe the diet of herbivores. However, we will also use them for omnivores and primates, which can incorporate non-vegetable foods in their diets, as well as for carnivores. Therefore, in the present study, $\mathrm{C}_{3}$ and $\mathrm{C}_{4}$ terms also refer to the exploitation of resources provided from environment dominated by either $\mathrm{C}_{3}$ or $\mathrm{C}_{4}$ plants, and not to the consumption of plant per se. Using plants $\delta^{13} \mathrm{C}$ values and enamel-diet spacing values, range of $\mathrm{C}_{3}, \mathrm{C}_{4}$ and mixed diets for herbivores, carnivores, omnivores and primates have been established and used to infer the Nam Lot palaeoenvironment according to faunal resource exploitation.

In homeothermic animals, the oxygen isotopic composition $\left(\delta^{18} \mathrm{O}\right)$ of tooth enamel is determined by the $\delta^{18} \mathrm{O}$ value of body water, which is itself mainly influenced by drinking water and chemically-bound water in the diet (Longinelli, 1984; Luz et al., 1984; Bryant and Froelich, 1995; Kohn et al., 1996; Fricke et al., 1998a, Fricke et al., 1998b). This in turn varies primarily according to the latitude and climate, where temperature, moisture content, amount of precipitation and isotopic composition of precipitation influence the $\delta^{18} \mathrm{O}$ values of local water (Dansgaard, 1964; Longinelli, 1984; Kohn and Cerling, 2002). In tropical and subtropical regions, it has been shown that the $\delta^{18} \mathrm{O}$ values of vegetation mostly reflect either evaporative potential or the source-effect of rainfall (Buchmann et al., 1997; Buchmann and Ehleringer, 1998; McCarroll and Loader, 2006).

As for $\delta^{13} \mathrm{C}$ values, $\delta^{18} \mathrm{O}$ can also be used to infer the density of a forest cover because of the canopy effect (Sternberg et al., 1989; Buchmann et al., 1997; Buchmann and Ehleringer, 1998). Flora and fauna living on the forest floor exhibit the lowest $\delta^{18} \mathrm{O}$ and $\delta^{13} \mathrm{C}$ values (van der Merwe and medina, 1991; Krigbaum, 2003; Krigbaum et al., 2013; Blumenthal et al., 2016; Roberts et al., 2017b). However, recent work demonstrated a lack of clear vertical $\delta^{13} \mathrm{C}$ values height stratification in plants within the canopy (Blumenthal et al., 2016), while $\delta^{18} \mathrm{O}$ values in vegetation, mostly leaves, are likely to be sensitive to a height gradient within and under the 
canopy (Sternberg et al., 1989; Cerling et al., 2004; Ometto et al., 2005; Krigbaum et al., 2013). This vertical gradient results in changing evaporative rate at different heights (Sternberg et al., 1989; Buchmann et al., 1997; Buchmann and Ehleringer, 1998; Ometto et al., 2005). However, it can be difficult in the absence of a local large dataset of tropical forest plants to distinguish low values caused by different evaporative rate rather than by different evaporative potential in plant parts (Roberts et al., 2017b). For example, leaf water will already exhibit higher $\delta^{18} \mathrm{O}$ values compared to other parts of the same plant (Gonfiantini et al., 1965; Dongmann et al., 1974; Epstein et al., 1977; Sternberg et al., 1989; Yakir, 1992).

\subsubsection{Tooth and enamel sample process}

A total of 51 teeth belonging to 17 taxa (among which 12 at a species level) were selected for the isotopic analysis of the Nam Lot fauna. One to six specimens per species were used. Preparation started with a thorough cleaning of the surface and the removing of a superficial layer of enamel in order to remove any exogenous or contaminant material and thus ensuring the quality of further isotopic analysis. About 4 to $13 \mathrm{mg}$ of enamel was obtained along the height of the crown of each tooth using a handheld Dremel@ drill equipped with a diamond-tipped bur. Powdered enamel samples were soaked in a solution of $1 \mathrm{~mL}$ of $0.1 \mathrm{M} / \mathrm{L}$ acetic acid $\left(\mathrm{CH}_{3} \mathrm{COOH}\right)$ for $4 \mathrm{~h}$ at room temperature in order to eliminate exogenous carbonates and then rinsed three times in distilled water. Samples were dried overnight at $65^{\circ} \mathrm{C}$.

Isotopic analyzes of pretreated enamel samples were performed at the "Service de Spectrométrie de Masse Isotopique du Muséum (SSMIM)" in Paris by a "Delta V Advantage" isotopic mass spectrometer coupled to a "Kiel IV Carbonate Device" chemical preparer (Thermo®). During each mass spectrometer run, eight analyses of the SSMIM internal laboratory standard (Marble LM) were performed for a total of forty measurements. The isotopic values of the internal laboratory standard $\left(\delta^{13} \mathrm{C}=+2.13 \%\right.$ and $\delta^{18} \mathrm{O}=-1.83 \%$ o $)$ are normalized to the international standard NBS-19 $\left(\delta^{13} \mathrm{C}=+1.95 \%\right.$ and $\delta^{18} \mathrm{O}=-2.20 \%$ ), and its repetitive measurement served to correct those of carbonate enamel samples run at the same time. It also serves to determine the precision of the mass spectrometer precision $\left(\sigma\left(\delta^{13} \mathrm{C}\right)=0.03 \%\right.$; $\sigma\left(\delta^{18} \mathrm{O}\right)=0.06 \%$ ). Homogeneity of the enamel samples was further estimated by the repeated analysis $(n=5)$ of two specimens (NL-63 and NL-65) and was $\pm 0.017 \%$ and $\pm 0.015 \%$ for $\delta^{13} \mathrm{C}$ and $\pm 0.136 \%$ ond $\pm 0.066 \%$ for $\delta^{18} \mathrm{O}$, respectively. Both carbon and oxygen isotopic values are presented in delta " $\delta$ " notation expressed as deviation \%o compared to the International Standard Vienna Pee Dee Belemnite (VPDB). 


\section{Results}

\subsection{Zooarchaeological data}

Nam Lot (86-72 ka) data demonstrate that the MIS 5 ecosystem in northeastern Laos clearly differed from that of the present-day with a larger spectrum of large herbivores. The ecosystem supported a high ungulate biomass, at least five types of ground-dwelling animals weighing from $\sim 250 \mathrm{~kg}$ up to $\sim 5000 \mathrm{~kg}$. The fauna records at least one rhinoceros species (900-2700 kg; Francis, 2008), one tapir (Tapirus indicus, 250-350 kg; Francis, 2008), the two proboscideans (Elephas sp., 3500-5000 kg; Francis, 2008) and Stegodon orientalis (3000-5000 kg; Schepartz and MillerAntonio, 2010), and at least two large bovid species (700-900 kg; Francis, 2008).

The analysis of the assemblage indicates a high degree of species interactions (Bacon et al., 2015). The abundance and diversity in ungulate prey species most likely favoured the presence of large populations of carnivores, as suggested by the presence of group-living predators, the dhole (Cuon alpinus, 10-21 kg; Francis, 2008), and the spotted hyena (Crocuta crocuta ultima, 45$80 \mathrm{~kg}$; Hayward, 2006). The age structure of pigs reveals the predominance of young and mature adult individuals (Sus scrofa, $\sim 30-60 \mathrm{~kg}$ ), which enters the prey-size category of both predators (Fig. 3SI). The age structure of rhinocerotids has a clear hyena-preyed signature (Fig. 4SI). At Nam Lot, hyena packs were efficient hunters and scavengers of rhinoceros calves, up to $\sim 400 \mathrm{~kg}$ (Laurie, 1982).

The MIS 4 Duoi U'Oi fauna (70-60 ka) contained a great diversity in large-bodied grounddwelling ungulates (cervids, bovids, and rhinocerotids) despite the absence of archaic species, Megatapirus augustus (up to $800 \mathrm{~kg}$; Janis, 1984), and Stegodon orientalis (up to $5000 \mathrm{~kg}$ ). The diversity of rhinoceroses is particularly notable with all three living Asian species recorded, Rhinoceros sondaicus, R. unicornis and Dicerorhinus sumatrensis (Antoine, 2012). What is striking is that the fauna is fully modern in its composition, and the chronology of the deposits (U-Th, $66 \pm 3 \mathrm{ka}$ ) (Bacon et al., 2008b), strengthened by two independent age estimates (U-Th and OSL, 70-60 ka) (Bacon et al., 2015), suggests that these changes were established by MIS 4 locally.

At Duoi U'Oi, the leopard (Panthera pardus, 45-65 kg; Francis, 2008) and the tiger (Panthera tigris, 180-245 kg; Francis, 2008) coexisted with the group-living dholes (10-21 kg). In this rich ungulate community, the age structure of pigs seems to be biased towards mature adult individuals, and among them the largest ones were preyed upon $(\sim 200 \mathrm{~kg})$ suggesting a tiger signature at the site (Karanth and Sunquist, 1995). No clear selectivity could be emphasized in 
the age structure of rhinoceroses, a pattern reflecting the natural attrition on a population (caused by disease, malnutrition, and/or hominin and non-hominin predators) (Figs. 3, 4SI).

The evidence of potential hominin contribution to the accumulation of the sambar deer remains (Cervus unicolor, 180-260 kg; Francis, 2008) has been identified based on age-at-death distribution of the prey species, in the absence of any further evidence (cut marks on bones, differential conservation of skeletal elements, etc.) (Fig. 3SI) (Bacon et al., 2015). The predominance of prime-adult individuals and the absence of old individuals in the mortality pattern likely represent a selective hunting where hominins primarily focused on the prime-aged members of the herd (Steele, 2003). To that respect, this mortality pattern differs from that generated by the tiger. Indeed, the sambar deer is among the preferred prey of the tiger (Hayward et al., 2012), but among adult animals killed, old-aged individuals are usually present (Karanth and Sunquist, 1995). A recent analysis of a late Middle Pleistocene fauna from northern Vietnam (Coc Muoi, 148-117 ka; Bacon et al., 2018), only composed of non-hominin large predators (tiger and dhole), is consistent with this observation made in current Indian ecosystems. Indeed, in the Coc Muoi mortality profile of the sambar deer, the adult category is represented by both prime-aged and old-aged individuals. This profile illustrates a pattern of possible attritional hunting of tigers, according to the availability and chance encounter with the prey (Schaller, 1967).

Overall, the two MIS 5-4 faunas demonstrate that the mainland ecosystems at the latitudes $\sim 21^{\circ} \mathrm{N}$ supported a large ungulate biomass. When considering MNI ungulates by body-size category - that may be considered as a good representation of hunted and/or scavenged carcasses of prey species accumulated at the sites - the percentages of animals $>176 \mathrm{~kg}$ are the highest (46.3\% and 59.1\% for Nam Lot and Duoi U'Oi, respectively) (Fig. 6). Comparatively, the medium (30-175 kg) and small (<30 kg) categories are much less significant (Fig. 6, Table 2SI). 


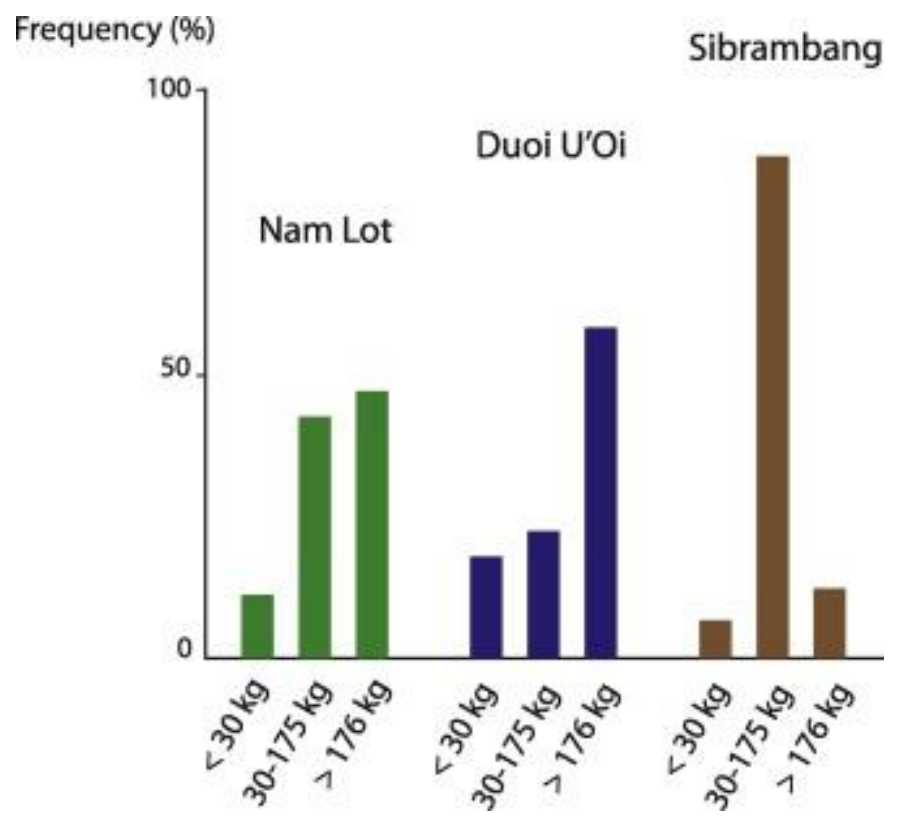

Fig. 6. MNI percentages by body-size category and age class (juvenile and adult) of ungulates in Late Pleistocene Southeast Asian faunas (modified from Bacon et al., 2015). The three body-size categories (small $<30 \mathrm{~kg}$; medium 30-175 kg; large $>176 \mathrm{~kg}$ ) are those used to study living populations by Karanth and Sunquist (1995).

3.2. Carbon and oxygen stable isotopic data $\left(\delta^{13} \mathrm{C}\right.$ and $\left.\delta^{18} \mathrm{O}\right)$ of the Nam Lot fauna $\delta^{13} \mathrm{C}$ results are presented in Table 3SI and Fig. 7. The 51 samples belonging to 17 taxa show $\delta^{13} \mathrm{C}$ values ranging from $-18.2 \%$ to $+0.3 \%$. The Bovidae have the highest intra-taxon variation $(13.8 \%)$, and C. crocuta the smallest $(0.1 \%)$. Herbivores $(\mathrm{n}=29)$ present values between $-18.2 \%$ (Stegodon cf. orientalis) and $+0.3 \%$ (Bovidae indet.), carnivores $(n=8)$ between $-15.3 \%$ (U. thibetanus) and $-12.6 \%$ (U. thibetanus), omnivores $(\mathrm{n}=9)$ between $-14.1 \%$ ( $S$. scrofa and $H$. brachyura) and $-12.1 \%$ (H. brachyura), and primates $(\mathrm{n}=5)$ between $-14.8 \%$ (Macaca sp.) and $-11.5 \%$ (Macaca sp.). The majority of individuals (90\%; $\mathrm{n}=46$ ) exhibit values associated with the resource exploitation of a $\mathrm{C}_{3}$ environment. Only a limited number of taxa exhibit values reflecting a $\mathrm{C}_{4}$ diet (Bovidae indet. $(\mathrm{n}=1)$ and Cervus unicolor $(\mathrm{n}=2)$ ) or a mixed diet $\mathrm{C}_{3} / \mathrm{C}_{4}$ (Bubalus bubalis $(\mathrm{n}=1)$ and Cervus unicolor $(\mathrm{n}=1)$ ). 


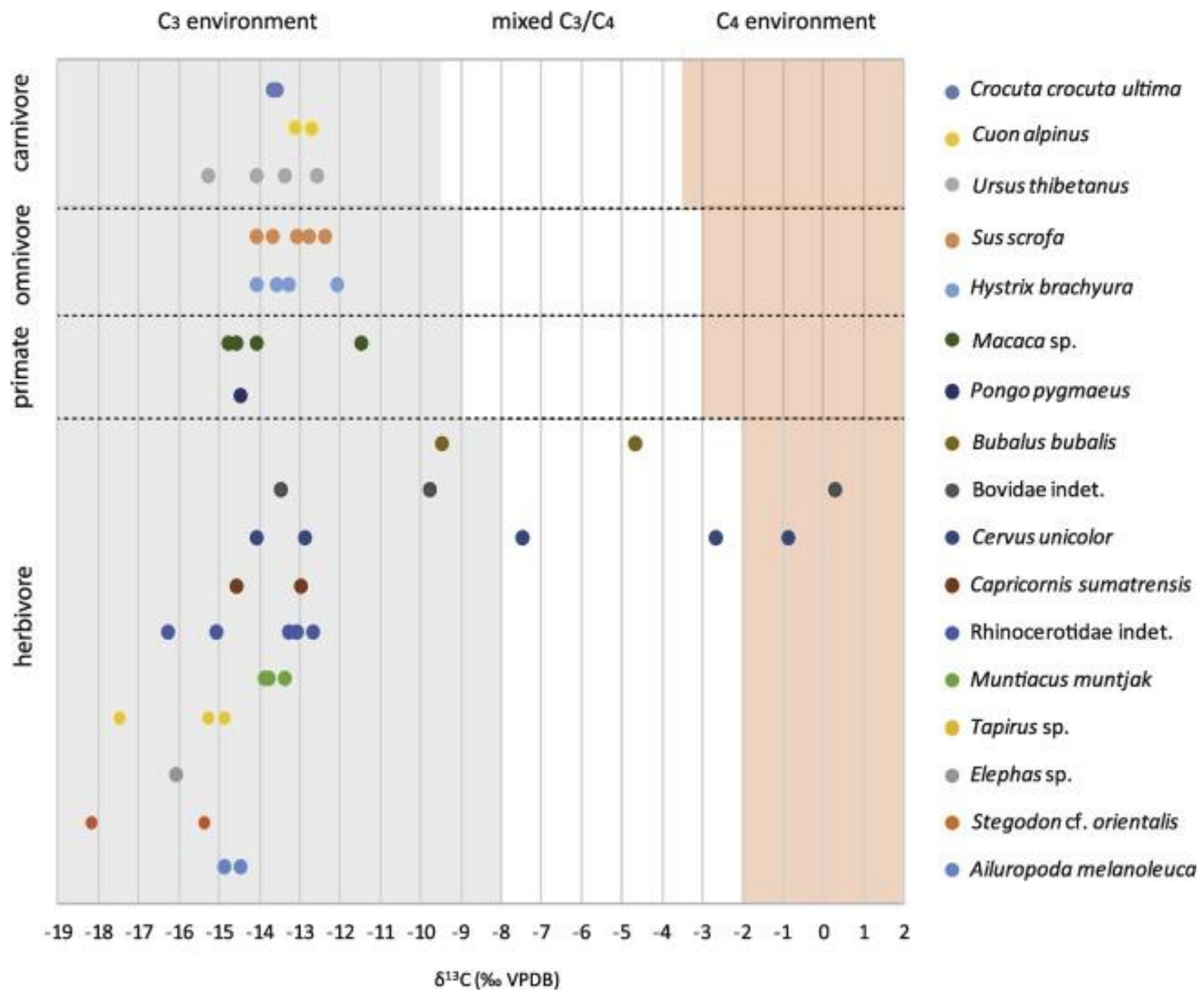

Fig. 7. Distribution of $\delta^{13} \mathrm{C}$ values obtained within each taxon of the Nam Lot fauna. The following limits were established in order to differentiate the diets of the different individuals of herbivores: $\mathrm{C}_{3}=\delta^{13} \mathrm{C}<-8.0 \%$, mixed $=-8.0 \%{ }_{0}>\delta^{13} \mathrm{C}<-2.0 \%$, $\mathrm{C}_{4}=\delta^{13} \mathrm{C}>-2.0 \%$ (Lee-Thorp et al., 1989; Cerling and Harris, 1999; Passey et al., 2005); carnivores: $\mathrm{C}_{3}=\delta^{13} \mathrm{C}<-9.5 \%$, mixed $=-9.5 \%>\delta^{13} \mathrm{C}<-3.5 \%, \mathrm{C}_{4}=\delta^{13} \mathrm{C}>-3.5 \%$ (LeeThorp et al., 1989; Fox-Dobbs et al., 2006); and omnivores and primates: $\mathrm{C}_{3}=\delta^{13} \mathrm{C}<-9.0 \%$, mixed $=-9.0 \%{ }_{0}>\delta^{13} \mathrm{C}<-3.0 \%, \mathrm{C}_{4}=\delta^{13} \mathrm{C}>-3.0 \%$ (Passey et al., 2005; Cerling et al., 2004; Sponheimer et al., 2013).

The lowest end of Nam Lot faunal range, $-18.2 \%$ to $-14.0 \% 0(\sim 4 \%, \mathrm{n}=21)$, is representative of closed low-light tropical rainforests (Cerling et al., 2004; Levin et al., 2008; Roberts et al., 2015, Roberts et al., 2017a). Intermediate values, from $-14.0 \%$ to $-11.0 \%$ ( $43 \%, \mathrm{n}=23)$, encompass the highest proportion of the specimens. These values can either reflect more open forest 
conditions similar to those of modern intermediate rainforests like Sri Lanka (annual rainfall of 1700-2200 mm) (Erdelen, 1988; Roberts et al., 2015, Roberts et al., 2017a), or a mixed dietary reliance going from closed forests to open $\mathrm{C}_{3}$ environments (e.g., Sponheimer et al., 2006; Levin et al., 2008; Roberts et al., 2015, Roberts et al., 2017a). However, the taxa that exhibit $\delta^{13} \mathrm{C}$ values between $-18.2 \%$ and $-11.0 \%$ include primates, rodents and other mammals that are known to prefer forest foraging. The majority of values found between $-14.0 \%$ and $-11.0 \%$ are thus likely to represent the acquisition of resources from a forest structure similar to that of modern intermediate rainforests rather than a mixed dietary reliance ranging from closed forests to open $\mathrm{C}_{3}$ environments (Roberts et al., 2015, Roberts et al., 2017a). A similar trend was first exposed at Balangoda Kuragala $(\sim 15,000 \pm 3000$ cal. years BP), Sri Lanka (Roberts et al., 2015, Roberts et al., 2017a). Additionally, there is a striking contrast with taxa present in the highest end of the $\delta^{13} \mathrm{C}$ range, $-11.0 \%$ to $+0.3 \%$ o $(\sim 14 \%, \mathrm{n}=7)$. These three taxa (B. bubalis, Bovidae indet., and $C$. unicolor) are all known to show a great variability in their grazing behavior. $\delta^{13} \mathrm{C}$ values of $-11.0 \%$ o to $+0.3 \%$ are likely to stem from a variable contribution of $\mathrm{C}_{4}$ resources present within a mixed forest/woodland/‘savanna' C 3 environment (e.g. Cerling and Harris, 1999; Cerling et al., 2004, Cerling et al., 2015; Sponheimer et al., 2006; Levin et al., 2008; Roberts et al., 2015, Roberts et al., 2017a).

Large ungulates (B. bubalis, Bovidae indet., and C. unicolor) exhibit the highest variation in $\delta^{13} \mathrm{C}$ values $(-14.1 \%$ to $+0.3 \%$ ), suggesting an opportunistic feeding behavior and habitat foraging from closed forest and intermediate rainforest to open grassland. Smaller ungulates and other ground-dwelling taxa ( $C$. sumatrensis, M. muntjak, S. scrofa, and H. brachyura) display a more restricted isotopic range $(-14.6 \%$ o to $-12.1 \%$ ) and most likely relied on open intermediate rainforests. Megaherbivores (Tapirus sp., Elephas sp., and Stegodon) with the exception of the rhinoceros $\left(\delta^{13} \mathrm{C}\right.$ values from $-18.1 \%$ to $-14.9 \%$ ) show a comparable reliance on exclusively closed low-light forest resources $(-18.1 \%$ to $-14.9 \%$ ). Although some individuals among rhinoceroses present values consistent to that of most megaherbivores, some others present higher values $(-16.3 \%$ o to $-12.7 \%$ ) associated with open intermediate rainforests. This partitioning could be explained by the difference in dietary preference between different species, but not recognized here based on dental morphology. Primates (Macaca sp., and P. pygmaeus) $\delta^{13} \mathrm{C}$ values $(-14.8 \%$ o to $-11.5 \%$ ) fall within a similar range than that seen in Asia through the literature (e.g., Pushkina et al., 2010; Roberts et al., 2015, Roberts et al., 2017a; Bocherens et al., 2017). When compared to extinct and extant specimens, Nam Lot giant pandas A. melanoleuca exhibit lower $\delta^{13} \mathrm{C}$ values $(-14.9 \%$ and $-14.5 \%$ ) although still within the range of a diet 
composed of foodstuff (most likely bamboo) found in closed canopy environments (e.g., Stacklyn, 2016; Bocherens et al., 2017; Ma et al., 2017; Stacklyn et al., 2017). U. thibetanus exhibits low $\delta^{13} \mathrm{C}$ values ( $-15.3 \%$ to $-12.6 \%$ ), with some samples falling within the range of the lowest end of $\delta^{13} \mathrm{C}$ values, attesting to a reliance on closed forest environments. Finally, $C$.

crocuta ultima and $C$. alpinus both exhibit relatively low values $(-13.7 \%$ to $-13.0 \%)$ that would result from the consumption of prey whose diet reflects intermediate rainforest foodstuff, or more likely the consumption of prey which relied on mixed vegetation, from closed forest to open $\mathrm{C}_{3}$ $\mathrm{C}_{4}$ environments.

$\delta^{18} \mathrm{O}$ results are presented in Table 3SI and Fig. 8. $\delta^{18} \mathrm{O}$ values range from $-9.0 \%$ (U. thibetanus) to $-2.5 \%$ (Rhinocerotidae indet.), $U$. thibetanus having the largest inter-individual amplitude (5.9\%o), and $C$. crocuta ultima the smallest $(0.3 \%)$. Herbivores $(\mathrm{n}=29)$ exhibit $\delta^{18} \mathrm{O}$ values between $-8.7 \%$ ( $C$. unicolor) and $-2.5 \%$ (Rhinocerotidae indet.), while those of carnivores $(\mathrm{n}=8)$ vary from $-9.0 \%$ (U. thibetanus) to $-3.0 \%$ (C. alpinus). Both omnivores $(\mathrm{n}=9)$ and primates $(\mathrm{n}=5)$ have a narrower range of $\delta^{18} \mathrm{O}$ values, between $-6.8 \%$ (S. scrofa) and $-5.2 \%$ o $(H$. brachyura), and between -6.1\%o (Macaca sp., and Pongo pygmaeus) and -3.6\%o (Macaca sp.), respectively.

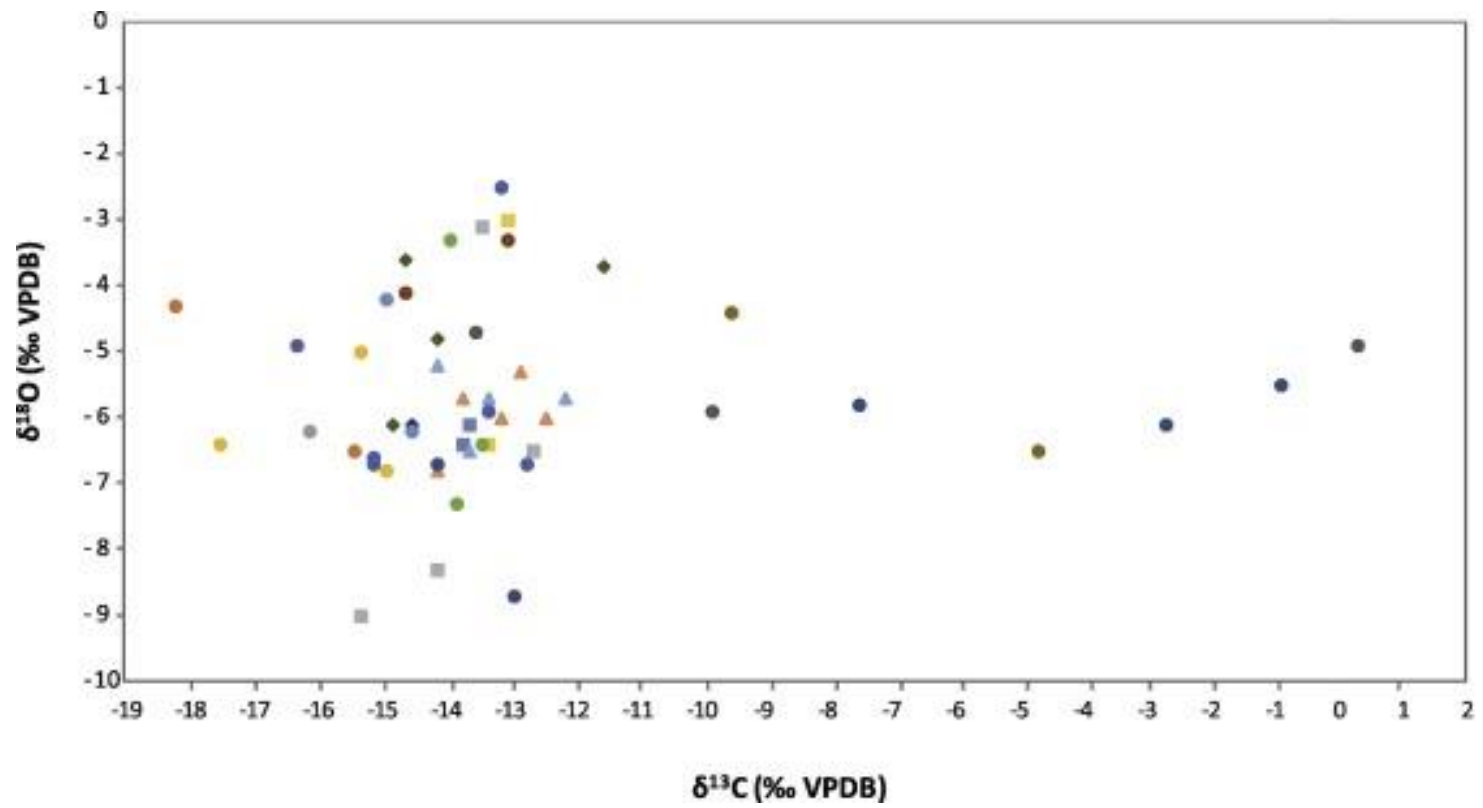

- Crocuta crocuta ultima

- Cuon alpinus

= Ursus thibetanus

- Susscrofa

4 Hystrix brachyura

- Macaca sp.

- Pongo pygmaeus

- Bubalus bubalis

- Bovidae indet.

- Cervus unicolor

- Capricornis sumatrensis

- Rhinocerotidae indet.

- Muntiacus muntjak

- Tapirus sp.

- Elephassp.

- Stegodon cf. orientalis

- Ailuropoda melanoleuca

Fig. 8. Distribution of $\delta^{13} \mathrm{C}$ and $\delta^{18} \mathrm{O}$ values at the individual level for each taxon of the Nam Lot fauna. 
Unexpectedly, most large ungulates (B. bubalis, Bovidae indet., and C. unicolor) exhibit a somewhat narrow range of $\delta^{18} \mathrm{O}$ values when compared to their respective range of $\delta^{13} \mathrm{C}$ values. Indeed, a combination of relatively high $\delta^{18} \mathrm{O}$ and $\delta^{13} \mathrm{C}$ values could have been expected as a likely result of feeding and drinking in open $\mathrm{C}_{4}$ environments. However, most of these individuals, which likely incorporated $\mathrm{C}_{4}$ plants present values $(-6.5 \%$ to $-4.4 \%$; mean $=-5.5 \pm 0.7 \%$ ) close to the bulk of population $\delta^{18} \mathrm{O}($ mean $=-5.7 \pm 1.4 \%$ ). Likewise, the megaherbivores (Tapirus sp., Elephas sp., S. cf. orientalis, and Rhinocerotidae indet.) which display the lowest $\delta^{13} \mathrm{C}$ values were consequently expected to display the lowest $\delta^{18} \mathrm{O}$ values, following the same depletion trend of the canopy effect. With the exception of a single rhinoceros individual exhibiting a high $\delta^{18} \mathrm{O}$ value $\left(-2.5 \%\right.$ ), they all nevertheless exhibit $\delta^{18} \mathrm{O}$ values $(-6.8 \%$ o to $-4.3 \%$; mean $=-6.0 \pm 0.9 \%$ ) close to that of the bulk of the population. The grounddwelling S. scrofa and $H$. brachyura both display a similar and narrow range of $\delta^{18} \mathrm{O}(-6.8 \%$ o to $-5.2 \%$ ), as does the $C$. crocuta ultima hyena, falling precisely within the bulk of population $\delta^{18} \mathrm{O}$. Surprisingly, the $\delta^{18} \mathrm{O}$ value obtained for the arboreal orangutan $P$. pygmaeus $(-6.1 \%$ ) does not differ significantly from all of these previously mentioned ground-dwelling taxa. Macaca however displays mostly high $\delta^{18} \mathrm{O}$ values $(-6.1 \%$ o to $-3.6 \%$; mean $=-4.6 \pm 1.2 \%$ ). This dissimilarity in $\delta^{18} \mathrm{O}$ values observed between the two primate taxa may be explained by dietary differences, and by the fact that macaques drink most likely more open water. Owing to different evaporative potentials, the chemically-bound water found in leaves exhibit higher $\delta^{18} \mathrm{O}$ values compared to other parts of the same plant (Gonfiantini et al., 1965; Dongmann et al., 1974; Epstein et al., 1977; Sternberg et al., 1989; Yakir, 1992), resulting also possibly in the higher $\delta^{18} \mathrm{O}$ values in macaques than in orangutans. All of the other taxa exhibit either relatively high $\delta^{18} \mathrm{O}$ values $\left(C\right.$. sumatrensis; $-4.1 \%$ to $-3.3 \%$ ) or a mix of both high and low $\delta^{18} \mathrm{O}$ values $(M$. muntjak, $C$. alpinus, $U$. thibetanus, and A. melanoleuca; $-8.3 \%$ to $-3.0 \%$ ). These higher values result most likely in feeding and drinking behavior in more open $\mathrm{C}_{3}$ environment, when compared to the bulk of population $\delta^{18} \mathrm{O}$.

As it is the case with the $\delta^{13} \mathrm{C}$ values, a large range of $\delta^{18} \mathrm{O}$ values can be observed at Nam Lot $(-9.0 \%$ o to $-2.5 \%$ ) as already observed for other Asian sites (e.g., Pushkina et al., 2010; Roberts et al., 2015, Roberts et al., 2017a; Bocherens et al., 2017). However, while most $\delta^{13} \mathrm{C}$ values were consistent with known species behavior, diet and habitat preferences, $\delta^{18} \mathrm{O}$ values are somewhat more complex to interpret. At the intraspecific level, such isotopic variability may be explained by variability in diet and drinking intakes (Bryant and Froelich, 1995; Kohn et al., 1996; Fricke et al., 1998a, Fricke et al., 1998b; Kohn and McKay, 2012). The largest variability in $\delta^{18} \mathrm{O}$ values, 
associated to $\delta^{13} \mathrm{C}$ values showing dietary reliance on open forest or a mixed closed forest to open $\mathrm{C}_{3}$ environment, could be linked to the large range of coexisting habitats at Nam Lot. An alternative explanation is a variation in the ${ }^{18} \mathrm{O}$ values of meteoric waters and environmental conditions over the deposition/accumulation time. As the faunal assemblage of Nam Lot is constrained between 86 and $72 \mathrm{ka}$, the variability in ${ }^{18} \mathrm{O}$ values could be the result of climatic changes, which occurred around $70 \mathrm{ka}$, during the termination of MIS 5. A larger dataset could help to elucidate the high intraspecific variations observed for $\delta^{13} \mathrm{C}$ or $\delta^{18} \mathrm{O}$ at Nam Lot and other Asian sites.

\section{Discussion}

4.1. MIS5 environmental context in northeastern Laos

The Nam Lot data provide a description of the palaeoenvironment during the terminal phase of MIS $5(\sim 128-71 \mathrm{ka})$. No reliable evidence supports for the moment the presence of modern humans during that period in the north of the Indochinese region.

The range of $\delta^{13} \mathrm{C}$ values of animals is large with a strong predominance of $\mathrm{C}_{3}$ resources in the diet $(90 \%, \mathrm{n}=46)$, with very few taxa (e.g., large bovids and sambar deer) confidently exploiting $\mathrm{C}_{4}$ resources $(10 \%, \mathrm{n}=5)$. While $\delta^{18} \mathrm{O}$ values cannot be fully explained yet, the variability in $\delta^{13} \mathrm{C}$ and $\delta^{18} \mathrm{O}$ values seen in the Nam Lot material is nevertheless consistent with that observed in other Asian sites (e.g., Pushkina et al., 2010; Roberts et al., 2015, Roberts et al., 2017a; Bocherens et al., 2017), and most notably at Balangoda Kuragala and Batadomba-Lena (Roberts et al., 2015, Roberts et al., 2017a) where similar palaeoecological trends can be observed. Both zooarchaeological data and $\delta^{13} \mathrm{C}$ values attest to the existence of a mosaic of habitats. Furthermore, the Nam Lot isotopic results bring insight and precision to the nature of the forest cover during the terminal phase of MIS 5 in northeastern Laos. $\delta^{13} \mathrm{C}$ values indicate a complexity in the forest habitats with closed low-light tropical rainforests, "intermediate" rainforests, and $\mathrm{C}_{3}-\mathrm{C}_{4}$ open woodlands/'savannas'. This woodland ecosystem - notably the "intermediate" rainforest - carried most of the ungulate biomass, with a variety of small to large-bodied animals on the ground, including muntjac, wild pig, sambar deer, serow, wild cattle, and rhinoceros, which is strong evidence of a high primary productivity biomass with high production of edible plant material (Geist, 1974; Eisenberg and Seidensticker, 1976). In this ecosystem-type, tapir, elephant and Stegodon were particularly adapted to canopied woodlands, as also emphasized for southern Chinese ecosystems (Bocherens et al., 2017; Li et al., 2017; Ma et al., 2017). The Nam Lot zooarchaeological and isotopic results also provide the first unequivocal evidence for the presence of open woodland and savanna zones at these latitudes $\left(\sim 20^{\circ} \mathrm{N}\right)$ during the MIS 5 
warm and humid period. These zones most likely constituted a relatively attractive environment for predators. Open areas along watercourses or swamps and grassland are interesting habitats to forage, considering the need of abundant water for rhinoceroses and large cattle like buffaloes, and aptitude for most of the forest-living species, especially sambar, wild pig, and water buffalo, to gregariousness in open areas (Schaller, 1967; Eisenberg and Lockhart, 1972; Lekagul and McNeely, 1997; Nowak, 1999; Leslie, 2011; Ramesh et al., 2012).

In the mosaic environment of Nam Lot, the importance of these intermediate and open zones as ecosystems rich in prey species, is supported by the hunting lifestyle of large predators. At Nam Lot, the spotted hyenas and dholes had access to a large spectrum of terrestrial prey species. Rhinoceroses were exclusive resources for hyenas, whereas wild pigs were most likely preyed upon by hyenas and dholes taking into account their highly probable abundance in this moist habitat-type (Bacon et al., 2015). The kill of juvenile rhinoceroses weighing up to $400 \mathrm{~kg}$ required obligate hunting in packs (of about 15 hyenas according to Kruuk, 1972) which could have been difficult in a closed forested vegetation. Observations made in Africa support this assumption. When the kills of hyenas involve the largest prey, buffaloes (200-400 kg, up to $13 \%$ ) and elands ( $>400 \mathrm{~kg}$, up to $2 \%$ ) in open savannas, hyenas hunt in large packs (Kruuk, 1972; Cooper et al., 1999; Höner et al., 2002). The difference with the MIS 5 equatorial ecosystem of Sibrambang of comparable age is particularly notable. At Sibrambang, predators had access to a more restricted spectrum of prey, among medium-sized mammals (Figs. 6, 1SI, 3SI, 4SI). No reliable evidence supports for the moment the presence of modern humans during MIS 5 in northeastern Laos, before $70 \mathrm{ka}$. However, signs of an expansion in the time range of $\sim 120-70 \mathrm{ka}$ in South Asia (Petraglia et al., 2007; Armitage et al., 2011; Blinkhorn et al., 2013; Groucutt et al., 2015), as far as Java (Storm et al., 2005; Storm and de Vos, 2006; Westaway et al., 2007), and in central to south China (Liu et al., 2010a, Liu et al., 2010b, Liu et al., 2015; Cai et al., 2017; Shen et al., 2013; Bae et al., 2014), support the idea of multiple MIS 5 dispersal events.

In the plausible scenario that modern humans entered Southeast Asia during MIS 5, a Nam Lottype habitat could have constituted a relatively attractive environment for people with small to large game available and exploitable on the ground. The presence of intermediate zones in rainforest environments, open forests, forest-edges, and grassland zones rich in prey species, could have procured many tuberous and leafy species for food (Hunt et al., 2012; Roberts et al., 2017a, Roberts et al., 2017b). 


\subsection{MIS 4 environmental context in northern Vietnam}

When comparing the Nam Lot fauna with that of Duoi U'Oi (70-60 ka), the climatic fluctuations between MIS 5 ( 128-71 ka) and MIS 4 ( 71-52 ka) did not seemingly modify the abundance of forest-dependent species, especially that of pigs and rhinoceroses. The MIS 4 biotope supported a large variety of small to large ungulates, including muntjac, wild pig, deer, tapir, rhinoceros, and elephant. Macaques remained much more abundant than orangutans (compared to more southern latitudinal sites such as Sibrambang; Table 1SI). In terms of biodiversity, the major climatedriven change observed in the Duoi U'Oi fauna is the absence of the largest ungulate species, Stegodon orientalis. The absence of the giant tapir (Megatapirus augustus) - recorded in most MIS 5 faunas in northern Indochina and southern China - is also notable (Cuong, 1985, Cuong, 1992; Olsen and Ciochon, 1990; Wu and Poirier, 1995; Bacon et al., 2008a, Bacon et al., 2011; Wang et al., 2007; Rink et al., 2008). The last Interglacial-glacial shift, characterized by changes in the intensity of the East Asian monsoon (Wang et al., 2008), was marked at the latitudes $\sim 20^{\circ} \mathrm{N}$ by the onset of relatively cool and wet conditions (with $\sim 4{ }^{\circ} \mathrm{C}$ cooler temperatures than present), that contributed to important changes in rainforest composition (Zheng and Lei, 1999). Perhaps, the forest-type of Duoi U'Oi could not support locally such high ungulate biomass, most likely correlated with the reduction of the low-light canopy area (ongoing isotopic analysis of the Vietnamese Duoi U'Oi fauna (70-60 ka) compared to that of Coc Muoi (148-117 ka) will allow us to test this hypothesis). Based on the vegetation component of the site, the area might be composed of more open forests, as suggests the low percentage (8\%) of arboreal and shrub pollens, in comparison with that of non-arboreal and fern spores (56\%) (Fig. 2SI). Furthermore, the abundance of the sambar deer, might also point to the presence of more extensive mixed and open areas, considering the flexibility of its diet by browsing or by grazing depending on the habitat (Leslie, 2011).

Nevertheless, this MIS 4 rainforest environment continued to guarantee a large spectrum of small to large terrestrial game. The presence of sympatric species within the large carnivore guild, such as tiger, leopard and dhole, is strong evidence for the abundance of prey-species, as well as their availability in different size classes, on the ground and in arboreal strata (Hayward et al., 2006, Hayward et al., 2012, Hayward et al., 2014, and references therein). Tigers, which were most likely the main predators at the site, prefer to hunt in wooded and open areas by stalking their prey.

At Duoi U'Oi, the foraging economy practiced by hominins most likely contained a great representation of terrestrial animals. The small representation of arboreal and semi-arboreal 
species which constitute $27.2 \%$ of the assemblage, differs from that of more recent sites (MIS 32), such as Niah cave in Borneo with 31.8\% ( 50 ka; Barker et al., 2007), and 56.1\% at Lobang Hangus (Terminal Pleistocene; Piper and Rabett, 2009), in which the increase of hunted prey coincides with efficient hunting technologies, particularly with the use of bone technology. Another example comes from the settlement of Homo sapiens in the rainforest of inland Sri Lanka, at Batadomba-lena rockshelter ( 36 ka to Holocene; Perera et al., 2011), where arboreal and semi-arboreal species $<20 \mathrm{~kg}$ constitute up to $82 \%$ of all animals recorded (Table 1 ). This procurement of diverse resources is associated with evidence of behavioral modernity (microlithic industries, composite tools, practice of symbolism, and ritual).

Table 1. Percentages of arboreal and mixed arboreal/terrestrial faunas in Asian sites.

Borneo

Niah cave (West Mouth)

$\sim 50-0.25 \mathrm{ka}$

$31.8 \%$
Niah cave (Lobang Hangus) $\sim 10 \mathrm{ka}$

$56.1 \%$
Sri Lanka

Batadomba-Iena $\sim 36-12 \mathrm{ka}$

$82 \%$
Vietnam

Duoi U'Oi $\sim 70-60 \mathrm{ka}$

$27.2 \%$

NISP percentages of arboreal (monkey and ape) and mixed arboreal/terrestrial (squirrel, civet, and bear cat) faunas calculated for Homo sapiens sites: Niah cave, the Hell Trench of the West Mouth (data calculated from Table 1 in Barker et al., 2017); Niah cave, Lobang Hangus (data calculated from Fig. 5 in Piper and Rabett, 2009); Batadomba-Iena (data from Perera et al., 2011); and for the hominin Duoi U'Oi site (this paper).

If there is growing evidence that hominins lived in Southeast Asian various rainforest contexts Homo sapiens at Tam Pà Ling ( 70-46 ka; Demeter et al., 2017; Shackelford et al., 2018) and Lida Ajer (73-63 ka; Westaway et al., 2017), and an unidentified hominin at Callao ( 66.7 ka; Mijares et al., 2010), and Duoi U'Oi (70-60 ka; the present analysis) - there are no however direct evidence for the moment that they were using the rainforest, and their degree of reliance on these habitats remains to be demonstrated.

The lack of artefacts (made from bone, stone, antlers or plants, charcoal, ornaments, traps, and other kind of manifestations) associated with hominin remains in MIS 5-4 Indochinese sites is obviously an impediment to our understanding of their adaptive skills, and particularly those of the earliest modern humans when expanding into the Southeast Asia. At present, there is no evidence of any of the innovations described in the other sites of comparable age (McBrearty and 
Brooks, 2000; Norton and Jin, 2009; Petraglia et al., 2012; Kaifu et al., 2015; d'Errico et al., 2017; Bae, 2017), except the potential occupation within rock shelters rather than open-air sites in karstic landscapes, further inducing a lower probability for fossil preservation and/or discovery (Morley, 2017).

\section{Conclusions}

The Nam Lot isotopic results indicate a large range of coexisting habitats in northeastern Laos during MIS 5 with closed low-light tropical rainforests, "intermediate" rainforests, and $\mathrm{C}_{3}-\mathrm{C}_{4}$ open woodlands/'savannas'. This woodland ecosystem - notably the "intermediate” rainforest carried most of the ungulate biomass, with a variety of small to large-bodied ground-dwelling animals. The zooarchaeological data indicate a high degree of species interactions, as suggested by the presence of group-living predators.

The Duoi U'Oi zooarchaeological results also show that, during MIS 4, the locality constituted a relatively attractive environment for predators (hominins and non-hominins). The foraging economy practiced by hominins most likely contained a great representation of terrestrial animals.

\section{Acknowledgments}

We thank the Director Samlane Luangaphay of the Department of National Heritage, Ministry of Information and Culture in Vientiane, Laos, for his authorization to study the Nam Lot fauna in 2016. We thank Olivier Tombret (UMR 7208; LabEx ANR-10-LABX-0003-BCDiv) for his help during sample pretreatment and Denis Fiorillo (SSMIM, UMR 7209) who performed the isotopic analysis at the SSMIM. We thank Christopher Bae for his invitation to contribute to this special issue, and reviewers for their useful comments. We thank particularly Kira Westaway for the time she invested in editing the manuscript. This research was in part funded by the Department of Human Evolution (Prof. Jean-Jacques Hublin), Max Planck Institute for Evolutionary Anthropology, Leipzig, to Nicolas Bourgon (contract number 0117/037).

\section{References}

Ambrose and Norr, 1993

S.H. Ambrose, L. Norr

Experimental evidence for the relationship of the carbon isotope ratios of whole diet and dietary protein to those of bone collagen and carbonate 
Prehistoric Human Bone, Springer Berlin Heidelberg (1993), pp. 1-37

Ambrose et al., 1997

S.H. Ambrose, B.M. Butler, D.B. Hanson, R.L. Hunter-Anderson, H.W. Krueger

Stable isotopic analysis of human diet in the Marianas Archipelago, Western Pacific

Am. J. Phys. Anthropol., 104 (1997), pp. 343-361

Antoine, 2012

P.-O. Antoine

Pleistocene and Holocene rhinocerotids (Mammalia, Perissodactyla) from the Indochinese Peninsula

C.R. Palevol, 11 (2012), pp. 159-168

Arambourg and Fromaget, 1938

C. Arambourg, J. Fromaget

Le gisement quaternaire de Tam Nang (Chaîne Annamitique septentrionale). Sa stratigraphie et ses faunes

C. R. Acad. Sci., 203 (1938), pp. 793-795

Armitage et al., 2011

S.J. Armitage, S.A. Jasim, A.E. Marks, A.G. Parker, V.I. Usik, H.P. Uerpmann

The Southern Route "Out of Africa": evidence for an early expansion of modern humans into Arabia

Science, 331 (2011), pp. 453-456

Bacon et al., 2008a

A.-M. Bacon, F. Demeter, C. Tougard, J. de Vos, T. Sayavongkhamdy, P.-O. Antoine, B. Bouasisengpaseuth, P. Sichanthongtip

Redécouverte d'une faune pléistocène dans les remplissages karstiques de Tam Hang au Laos : premiers résultats C.R. Palevol, 7 (2008), pp. 277-288 
Bacon et al., 2008b

A.-M. Bacon, F. Demeter, P. Duringer, C. Helm, M. Bano, Vu The Long, Nguyen Kim Thuy, P.O. Antoine, Bui Thi Mai, Nguyen Thi Mai Huong, Y. Dodo, F. Chabaux, S. Rihs

The Late Pleistocene Duoi U'Oi cave in northern Vietnam: palaeontology, sedimentology, taphonomy, palaeoenvironments

Quat. Sci. Rev., 27 (2008), pp. 1627-1654

Bacon et al., 2011

A.-M. Bacon, P. Duringer, P.-O. Antoine, F. Demeter, L. Shackelford, T. Sayavongkhamdy, P. Sichanthongtip, P. Khamdalavong, S. Nokhamaomphu, V. Sysuphanh, E. Patole-Edoumba, F. Chabaux, E. Pelt

The Middle Pleistocene mammalian fauna from Tam Hang karstic deposit, northern Laos: new data and evolutionary hypothesis

Quat. Int., 245 (2011), pp. 315-332

Bacon et al., 2012

A.-M. Bacon, F. Demeter, P. Duringer, E. Patole-Edoumba, T. Sayavongkhamdy, A.-S. Coupey, L. Shackelford, K. Westaway, J.-L. Ponche, P.-O. Antoine, P. Sichanthongtip

Les sites de Tam Hang, Nam Lot et Tam Pà Ling au nord du Laos. Des gisements à vertébrés du Pléistocène aux origines des Hommes modernes

Editions CNRS (2012)

(149 pp.)

Bacon et al., 2015

A.-M. Bacon, K. Westaway, P.-O. Antoine, P. Duringer, A. Blin, F. Demeter, J.-L. Ponche, J.-x. Zhao, L. Barnes, T. Sayavongkhamdy, Nguyen Thi Kim Thuy, E. Patole-Edoumba, Vu The Long, L. Shackelford

Late Pleistocene mammalian assemblages of Southeast Asia: new dating, mortality profiles and evolution of the predator-prey relationships in an environmental context Palaeogeogr. Palaeoclimatol. Palaeoecol., 422 (2015), pp. 101-127 
Bacon et al., 2018

A.-M. Bacon, P.-O. Antoine, Nguyen Thi Mai Huong, K. Westaway, Nguyen Anh Tuan, P. Duringer, J.-X. Zhao, J.-L. Ponche, Sam Canh Dung, Truong Huu Nghia, Tran Thi Minh, Pham Tranh Son, M. Boyon, Nguyen Thi Kim Thuy, A. Blin, F. Demeter

A rhinocerotid-dominated megafauna at the MIS6-5 transition: the late Middle Pleistocene Coc Muoi assemblage, Lang Son province, Vietnam

Quat. Sci. Rev., 186 (2018), pp. 123-141

Bae, 2017

C.J. Bae

Late Pleistocene human evolution in Eastern Asia: behavioral perspectives Curr. Anthropol., 58 (2017), pp. S514-S526

Bae et al., 2014

C.J. Bae, W. Wang, J. Zhao, S. Huang, F. Tian, G. Shen

Modern human teeth from Late Pleistocene Luna Cave (Guangxi), China

Quat. Int., 354 (2014), pp. 169-183

Bae et al., 2017

C.J. Bae, K. Douka, M.D. Petraglia

On the origin of modern humans: Asian perspectives

Science, 358 (6368) (2017), Article eaai9067

Balasse, 2002

M. Balasse

Reconstructing dietary and environmental history from enamel isotopic analysis: time resolution of intra-tooth sequential sampling

Int. J. Osteoarchaeol., 12 (2002), pp. 155-165

Barker et al., 2007 
G. Barker, H. Barton, M. Bird, P. Daly, I. Datan, A. Dykes, L. Farr, D. Gilbertson, B. Harrison, C. Hunt, T. Higham, L. Kealhofer, J. Krigbaum, H. Lewis, S. McLaren, V. Paz, A. Pike, P. Piper, B. Pyatt, R. Rabett, T. Reynolds, J. Rose, G. Rushworth, M. Stephens, C. Stringer, J. Thompson, C. Turney

The "human revolution" in lowland tropical Southeast Asia: the antiquity and behavior of anatomically modern humans at Niah cave (Sarawak, Borneo)

J. Hum. Evol., 52 (2007), pp. 243-261

Barker et al., 2017

G. Barker, C. Hunt, H. Barton, C. Gosden, S. Jones, L. Lloyd-Smith, L. Farr, B. Nyiri, S. O'Dennell

The 'cultured rainforests' of Borneo

Quat. Int., 448 (2017), pp. 44-61

Blinkhorn et al., 2013

J. Blinkhorn, H. Achyuthan, M. Petraglia, P. Ditchfield

Middle Paleolithic occupation in the Thar Desert during the Upper Pleistocene: the signature of a modern human exit out of Africa?

Quat. Sci. Rev., 77 (2013), pp. 233-238

Blumenthal et al., 2016

S.A. Blumenthal, J.M. Rothman, K.L. Chritz, T.E. Cerling

Stable isotopic variation in tropical forest plants for applications in primatology

Am. J. Primatol., 78 (2016), pp. 1041-1054

Bocherens, 2002

H. Bocherens

Preservation of isotopic signals $\left({ }^{13} \mathrm{C},{ }^{15} \mathrm{~N}\right)$ in Pleistocene mammals

Biogeochemical Approaches to Paleodietary Analysis (2002), pp. 65-88

Bocherens et al., 2011 
H. Bocherens, M. Stiller, K.A. Hobson, M. Pacher, G. Rabeder, J.A. Burns, T. Tütken, M. Hofreiter

Niche partitioning between two sympatric genetically distinct cave bears (Ursus spelaeus and Ursus ingressus) and brown bear (Ursus arctos) from Austria: isotopic evidence from fossil bones

Quat. Int., 245 (2011), pp. 238-248

Bocherens et al., 2017

H. Bocherens, F. Schrenk, Y. Chaimanee, O. Kullmer, D. Mörike, D. Pushkina, J.-J. Jaeger

Flexibility of diet and habitation in Pleistocene South Asian mammals: implications for the fate of the giant fossil ape Gigantopithecus

Quat. Int., 434 (2017), pp. 148-155

Boivin et al., 2013

N. Boivin, D.Q. Fuller, R. Dennell, R. Allaby, M.D. Petraglia

Human dispersal across diverse environments of Asia during the Upper Pleistocene Quat. Int., 300 (2013), pp. 32-47

Brain, 1981

C.K. Brain

The Hunters and the Hunted? An Introduction to African Cave Taphonomy The University of Chicago Press, Chicago and London (1981)

Bryant and Froelich, 1995

J.D. Bryant, P.N. Froelich

A model of oxygen isotope fractionation in body water of large mammals Geochim. Cosmochim. Acta, 59 (1995), pp. 4523-4537

Buchmann and Ehleringer, 1998

N. Buchmann, J.R. Ehleringer 
$\mathrm{CO}_{2}$ concentration profiles, and carbon and oxygen isotopes in $\mathrm{C}_{3}$ and $\mathrm{C}_{4}$ crop canopies Agric. For. Meteorol., 89 (1998), pp. 45-58

Buchmann et al., 1997

N. Buchmann, J.M. Guehl, T.S. Barigah, J.R. Ehleringer

Interseasonal comparison of $\mathrm{CO}_{2}$ concentrations, isotopic composition, and carbon dynamics in an Amazonian rainforest (French Guiana)

Oecologia, 110 (1997), pp. 120-131

Cai et al., 2017

Y. Cai, X. Qiang, X. Wang, C. Jin, Y. Wang, Y. Zhang, E. Trinkaus, Z. An

The age of human remains and associated fauna from Zhiren Cave in Guangxi, southern China Quat. Int., 434 (2017), pp. 84-91

Cerling and Harris, 1999

T.E. Cerling, J.M. Harris

Carbon isotope fractionation between diet and bioapatite in ungulate mammals and implications for ecological and paleoecological studies

Oecologia, 120 (1999), pp. 347-363

Cerling et al., 2004

T.E. Cerling, J.A. Hart, T.B. Hart

Stable isotope ecology in the Ituri Forest

Oecologia, 138 (2004), pp. 5-12

Cerling et al., 2013

T.E. Cerling, F.K. Manthi, E.N. Mbua, L.N. Leakey, M.G. Leakey, R.E. Leakey, F.H. Brown, F.E. Grine, J.A. Hart, P. Kaleme, H. Roche, K.T. Uno, B.A. Wood

Stable isotope-based diet reconstructions of Turkana Basin hominins

Proc. Natl. Acad. Sci., 110 (2013), pp. 10501-10506 
Cerling et al., 2015

T.E. Cerling, S.A. Andanje, S.A. Blumenthal, F.H. Brown, K.L. Chritz, J.M. Harris, J.A. Hart, F.M. Kirera, P. Kaleme, L.N. Leakey, M.G. Leakey, N.E. Levin, F. Kyalo Manthi, B.H. Passey, K.T. Uno

Dietary changes of large herbivores in the Turkana Basin, Kenya from 4 to $1 \mathrm{Ma}$

Proc. Natl. Acad. Sci., 112 (2015), pp. 11467-11472

Clarkson et al., 2017

C. Clarkson, Z. Jacobs, B. Marwick, R. Fullagar, L. Wallis, M. Smith, R.G. Roberts, E. Hayes, K. Lowe, X. Carah, A. Florin, J. McNeil, D. Cox, L.J. Arnold, Q. Hua, J. Huntley, H.E.A. Brand, T. Manne, A. Fairbairn, J. Shulmeister, L. Lyle, M. Salinas, M. Page, K. Connell, G. Park, K.

Norman, T. Murphy, C. Pardoe

Human occupation of northern Australia by 65,000 years ago

Nature, 547 (2017), pp. 306-310

Codron et al., 2005

D. Codron, J. Luyt, J.A. Lee-Thorp, M. Sponheimer, D. De Ruiter, J. Codron

Utilization of savanna-based resources by Plio-Pleistocene baboons: research letter

S. Afr. J. Sci., 101 (2005), pp. 245-248

Cooper et al., 1999

S.M. Cooper, K.E. Holekamp, L. Smale

A seasonal feast: long-term analysis of feeding behavior in the spotted hyaena (Crocuta crocuta) Afr. J. Ecol., 37 (1999), pp. 149-160

Corbet and Hill, 1992

G.B. Corbet, J.E. Hill

The mammals of the Indomalayan region

Natural History Museum Publications, Oxford University Press (1992)

Corny et al., 2017 
J. Corny, M. Galland, M. Arzarello, A.-M. Bacon, F. Demeter, D. Grimaud-Hervé, C. Higham, H. Matsumura, Nguyen Lan Cuong, Nguyen Thi Kim Thuy, Viet Nguyen, M. Oxenham, T. Sayavongkhamdy, F. Sémah, L.L. Shackelford, F. Détroit

Dental phenotypic shape variation supports a multiple dispersal model for anatomically modern humans in Southeast Asia

J. Hum. Evol., 112 (2017), pp. 41-56

Cuong, 1985

N.L. Cuong

Fossile Menschenfunde aus Nordvietnam

J. Herrmann, H. Ullrich (Eds.), Menschwerdung - Biotischer und gesellschaftlicher

Entwicklungsprozess, Akademieverlag, Berlin (1985), pp. 96-102

Cuong, 1992

N.L. Cuong

A reconsideration of the chronology of hominid fossils in Vietnam

Akazawa, The Evolution of Dispersion of Hominids in Asia (1992), pp. 321-335

Curnoe et al., 2016

D. Curnoe, X. Ji, H. Shaojin, P.S.C. Taçon, Y. Li

Dental remains from Longtanshan cave 1 (Yunnan, China), and the initial presence of anatomically modern humans in East Asia

Quat. Int., 400 (2016), pp. 180-186

Dansgaard, 1964

W. Dansgaard

Stable isotopes in precipitation

Tellus, 16 (1964), pp. 436-468

Demeter et al., 2004 
F. Demeter, A.-M. Bacon, Nguyen Kim Thuy, Vu The Long, H. Matsumura, Ha Huu Nga, M.

Schuster, Nguyen Mai Huong, Y. Coppens

An archaic Homo molar from Northern Vietnam

Curr. Anthropol., 45 (2004), pp. 535-541

Demeter et al., 2005

F. Demeter, A.-M. Bacon, Nguyen Kim Thuy, Vu The Long, P. Duringer, S. Roussé, Y.

Coppens, H. Matsumura, Y. Dodo, Nguyen Mai Huong, T. Anezaki

Discovery of a second human molar and cranium fragment in the late Middle to Late Pleistocene cave of Ma U'Oi (Northern Vietnam)

J. Hum. Evol., 48 (2005), pp. 393-402

Demeter et al., 2012

F. Demeter, L. Shackelford, A.-M. Bacon, P. Duringer, K. Westaway, T. Sayavongkhamdy, J. Braga, P. Sichanthongtip, P. Khamdalavong, J.-L. Ponche, H. Wang, C. Lundstrom, E. PatoleEdoumba, A.-M. Karpoff

Anatomically modern human in Southeast Asia (Laos) by $46 \mathrm{ka}$

Proc. Natl. Acad. Sci., 109 (2012), pp. 14375-14380

Demeter et al., 2015

F. Demeter, L. Shackelford, K. Westaway, P. Duringer, A.-M. Bacon, J.-L. Ponche, X. Wu, T. Sayavongkhamdy, J.-x. Zhao, L. Barnes, M. Boyon, P. Sichanthongtip, F. Sénégas, A.-M.

Karpoff, E. Patole-Edoumba, Y. Coppens, J. Braga

Early modern humans and morphological variation in Southeast Asia: fossil evidence from Tam Pa Ling, Laos

PLoS One, 10 (4) (2015), Article e0121193

Demeter et al., 2017

F. Demeter, L. Shackelford, K. Westaway, L. Barnes, Ph. Duringer, J. Dumoncel, F. Sénégas, J.L. Ponche, T. Sayavongkhamdy, J.-X. Zhao, P. Sichanthongtip, E. Patole-Edoumba, T. Dunn, A. Zachwieja, Y. Coppens, A.-M. Bacon

Early modern humans from Tam Pà Ling, Laos fossil review and perspectives Curr. Anthropol., 58 (2017), pp. S527-S538 
DeNiro and Epstein, 1978

M.J. DeNiro, S. Epstein

Influence of diet on the distribution of carbon isotopes in animals

Geochim. Cosmochim. Acta, 42 (1978), pp. 495-506

d'Errico et al., 2017

F. d'Errico, W.E. Banks, D.L. Warren, G. Sgubin, K. van Niekerk, C. Henshilwood, A.-L.

Daniau, M.F. Sánchez Goñi

Identifying early modern human ecological niche expansions and associated cultural dynamics in the South African Middle Stone Age

Proc. Natl. Acad. Sci., 114 (2017), pp. 7869-7876

Dongmann et al., 1974

G. Dongmann, H.W. Nürnberg, H. Förstel, K. Wagener

On the enrichment of $\mathrm{H}_{2}{ }^{18} \mathrm{O}$ in the leaves of transpiring plants

Radiat. Environ. Biophys., 11 (1974), pp. 41-52

Duringer et al., 2012

P. Duringer, A.-M. Bacon, T. Sayavongkhamdy, Nguyen Thi Kim Thuy

Karst development, breccias history, and mammalian assemblages in Southeast Asia: a brief review

C.R. Palevol, 11 (2012), pp. 133-157

Ehleringer and Monson, 1993

J.R. Ehleringer, R.K. Monson

Evolutionary and ecological aspects of photosynthetic pathway variation

Annu. Rev. Ecol. Syst., 24 (1) (1993), pp. 411-439

Ehleringer et al., 1986 
J.R. Ehleringer, C.B. Field, Z.F. Lin, C.Y. Kuo

Leaf carbon isotope and mineral composition in subtropical plants along an irradiance cline Oecologia, 70 (1986), pp. 520-526

Ehleringer et al., 1987

J.R. Ehleringer, Z.F. Lin, C.B. Field, G.C. Sun, C.Y. Kuo

Leaf carbon isotope ratios of plants from a subtropical monsoon forest

Oecologia, 72 (1987), pp. 109-114

Ehleringer et al., 1998

J.R. Ehleringer, B. Palma, H.A. Mooney

Carbon isotope ratios of Atacama Desert plants reflect hyperaridity of region in northern Chile Rev. Chil. Hist. Nat., 71 (1998), pp. 79-86

Eisenberg and Lockhart, 1972

J.F. Eisenberg, M. Lockhart

An ecological reconnaissance of Wilpattu National Park, Ceylon

Smithson. Contrib. Zool. (101) (1972), pp. 1-108

Eisenberg and Seidensticker, 1976

J.F. Eisenberg, J. Seidensticker

Ungulates in southern Asia: a consideration of biomass estimates for selected habitats Biol. Conserv., 10 (1976), pp. 293-308

Epstein et al., 1977

S. Epstein, P. Thompson, C.J. Yapp

Oxygen and hydrogen isotopic ratios in plant cellulose

Science, 198 (1977), pp. 1209-1215 
Erdelen, 1988

W. Erdelen

Forest ecosystems and nature conservation in Sri Lanka

Biol. Conserv., 43 (1988), pp. 115-135

Farquhar et al., 1989

G.D. Farquhar, J.R. Ehleringer, K.T. Hubick

Carbon isotope discrimination and photosynthesis

Annu. Rev. Plant Biol., 40 (1989), pp. 503-537

Field and Lahr, 2005

J.S. Field, M.M. Lahr

Assessment of the southern dispersal: GIS-based analyses of potential routes at Oxygen Isotope Stage 4

J. World Prehist., 19 (2005), pp. 1-45

Field et al., 2007

J.S. Field, M. Petraglia, M.M. Lahr

The southern dispersal hypothesis and the South Asian archaeological record: examination of dispersal routes through GIS analysis

J. Anthropol. Archaeol., 26 (2007), pp. 88-108

Fox-Dobbs et al., 2006

K. Fox-Dobbs, P.V. Wheatley, P.L. Koch

Carnivore specific bone bioapatite and collagen carbon isotope fractionations: case studies of modern and fossil grey wolf populations

AGU Fall Meeting Abstracts 53 (2006)

Francis, 2008

C.M. Francis 
A Field Guide to the Mammals of South-East Asia

New Holland Publishers, London (2008)

(392 pp.)

Fricke et al., 1998a

H.C. Fricke, W.C. Clyde, J.R. O'Neil

Intra-tooth variations in $\delta{ }^{18} \mathrm{O}\left(\mathrm{PO}_{4}\right)$ of mammalian tooth enamel as a record of seasonal variations in continental climate variables

Geochim. Cosmochim. Acta, 62 (1998), pp. 1839-1850

Fricke et al., $1998 b$

H.C. Fricke, W.C. Clyde, J.R. O'Neil, P.D. Gingerich

Evidence for rapid climate change in North America during the latest Paleocene thermal maximum: oxygen isotope compositions of biogenic phosphate from the Bighorn Basin (Wyoming)

Earth Planet. Sci. Lett., 160 (1998), pp. 193-208

Friedli et al., 1986

H. Friedli, H. Lötscher, H. Oeschger, U. Siegenthaler, B. Stauffer

Ice core record of the $13 \mathrm{C} / 12 \mathrm{C}$ ratio of atmospheric $\mathrm{CO}_{2}$ in the past two centuries

Nature, 324 (1986), pp. 237-238

Fromaget, 1940a

J. Fromaget

Les récentes découvertes anthropologiques dans les formations préhistoriques de la chaîne annamitique

Proceedings of the Third Congress of Prehistorians of the Far East, Singapore 1938 (1940), pp. 51-59

Fromaget, $1940 b$

J. Fromaget 
La stratigraphie des dépôts préhistoriques de Tam Hang (Chaîne Annamitique septentrionale) et ses difficultés

Proceedings of the Third Congress of Prehistorians of the Far East, Singapore 1938 (1940), pp. $60-70$

Geist, 1974

V. Geist

On the relationship of social evolution and ecology in ungulates

Am. Zool., 14 (1974), pp. 205-220

Gonfiantini et al., 1965

R. Gonfiantini, S. Gratziu, E. Tongiorgi

Oxygen isotopic composition of water in leaves

Isotopes and Radiation in Soil-Plant Nutrition Studies (1965), pp. 405-410

Graham et al., 2014

H.V. Graham, M.E. Patzkowsky, S.L. Wing, G.G. Parker, M.L. Fogel, K.H. Freeman

Isotopic characteristics of canopies in simulated leaf assemblages

Geochim. Cosmochim. Acta, 144 (2014), pp. 82-95

Groucutt et al., 2015

H.S. Groucutt, E.M.L. Scerri, L. Lewis, L. Clark-Balzan, J. Blinkhorn, R.P. Jennings, A. Parton, M.D. Petraglia

Stone tool assemblages and models for the dispersal of Homo sapiens out of Africa Quat. Int., 382 (2015), pp. 8-30

Hayward, 2006

M.W. Hayward

Prey preferences of the spotted hyaena (Crocuta crocuta) and degree of dietary overlap with the lion (Panthera leo)

J. Zool., 270 (2006), pp. 606-614 
Hayward et al., 2006

M.W. Hayward, P. Henschel, J. O'Brien, M. Hofmeyr, G. Balme, G.I.H. Kerley

Prey preferences of the leopard (Panthera pardus)

J. Zool., 270 (2006), pp. 298-313

Hayward et al., 2012

M.W. Hayward, W. Jedrzejewski, B. Jedrzewska

Prey preferences of the tiger Panthera tigris

J. Zool., 286 (2012), pp. 221-231

Hayward et al., 2014

M.W. Hayward, S. Lyngdoh, B. Habib

Diet and prey preferences of dholes (Cuon alpinus): dietary competition within Asia's predator guild

J. Zool., 294 (2014), pp. 255-266

Höner et al., 2002

O.P. Höner, B. Wachter, M.L. East, H. Hofer

The response of spotted hyaenas to long-term changes in prey populations: functional response and interspecific kleptoparasitism

J. Anim. Ecol., 71 (2002), pp. 236-246

Hunt et al., 2012

C.O. Hunt, D.D. Gilbertson, G. Rushworth

A 50,000-year record of late Pleistocene tropical vegetation and human impact in lowland Borneo

Quat. Sci. Rev., 37 (2012), pp. 61-80

Indriati et al., 2011 
E. Indriati, C.C. Swisher III, C. Lepre, R.L. Quinn, R.A. Suriyanto, A.T. Hascaryo, R. Grün, C.S. Feibel, B.L. Pobiner, M. Aubert, W. Lees, S.C. Antón

The age of the 20 meter Solo River terrace, Java, Indonesia and the survival of Homo erectus in Asia

PLoS One, 6 (2011), Article e21562

Janis, 1984

C. Janis

Tapirs as living fossils

Living Fossils, Springer New York (1984), pp. 80-86

Kaifu et al., 2015

Y. Kaifu, M. Izuho, T. Goebel, H. Sato, A. Ono

Emergence and Diversity of Modern Human Behavior in Paleolithic Asia

Texas A\&M University Press (2015)

Karanth and Sunquist, 1995

K.U. Karanth, M.E. Sunquist

Prey selection by tiger, leopard and dhole in tropical forests

J. Anim. Ecol., 64 (1995), pp. 439-450

Kohn, 2010

M.J. Kohn

Carbon isotope compositions of terrestrial C3 plants as indicators of (paleo)ecology and (paleo)climate

Proc. Natl. Acad. Sci., 107 (2010), pp. 19691-19695

Kohn and Cerling, 2002

M.J. Kohn, T.E. Cerling

Stable isotope compositions of biological apatite 
Rev. Mineral. Geochem., 48 (2002), pp. 455-488

Kohn and McKay, 2012

M.J. Kohn, M.P. McKay

Paleoecology of late Pleistocene-Holocene faunas of eastern and central Wyoming, USA, with implications for LGM climate models

Palaeogeogr. Palaeoclimatol. Palaeoecol., 326 (2012), pp. 42-53

Kohn et al., 1996

M.J. Kohn, M.J. Schoeninger, J.W. Valley

Herbivore tooth oxygen isotope compositions: effects of diet and physiology

Geochim. Cosmochim. Acta, 60 (1996), pp. 3889-3896

Krigbaum, 2003

J. Krigbaum

Neolithic subsistence patterns in northern Borneo reconstructed with stable carbon isotopes of enamel

J. Anthropol. Archaeol., 22 (2003), pp. 292-304

Krigbaum, 2005

J. Krigbaum

Reconstructing human subsistence in the West Mouth (Niah Cave, Sarawak) burial series using stable isotopes of carbon

Asian Perspect., 44 (2005), pp. 73-89

Krigbaum et al., 2013

J. Krigbaum, M.H. Berger, D.J. Daegling, W.S. McGraw

Stable isotope canopy effects for sympatric monkeys at Taï Forest, Côte d'Ivoire

Biol. Lett., 9 (2013), Article 20130466 
Kruuk, 1972

H. Kruuk

The Spotted Hyena. A Study of Predation and Social Behavior

The University of Chicago Press, Chicago and London (1972)

(335 pp.)

Laurie, 1982

W.A. Laurie

Behavioral ecology of the greater one-horned rhinoceros (Rhinoceros unicornis)

J. Zool., 196 (1982), pp. 307-341

Lee-Thorp and van der Merwe, 1987

J.A. Lee-Thorp, N.J. van der Merwe

Carbon isotope analysis of fossil bone apatite

S. Afr. J. Sci., 83 (1987), pp. 712-715

Lee-Thorp et al., 1989

J.A. Lee-Thorp, J.C. Sealy, N.J. van der Merwe

Stable carbon isotope ratio differences between bone collagen and bone apatite, and their relationship to diet

J. Archaeol. Sci., 16 (1989), pp. 585-599

Lee-Thorp et al., 2010

J.A. Lee-Thorp, M. Sponheimer, B.H. Passey, D.J. De Ruiter, T.E. Cerling

Stable isotopes in fossil hominin tooth enamel suggest a fundamental dietary shift in the Pliocene

Philos. Trans. R. Soc. Lond. B Biol. Sci., 365 (2010), pp. 3389-3396

Lekagul and McNeely, 1997

B. Lekagul, J.A. McNeely 
Mammals of Thailand

Association for the Conservation of the Wildlife, Bangkok (1997)

Leslie Jr., 2011

D.M. Leslie Jr.

Rusa unicolor (Artiodactyla: Cervidae)

Mamm. Species, 43 (2011), pp. 1-30

Levin et al., 2008

N.E. Levin, S.W. Simpson, J. Quade, T.E. Cerling, S.R. Frost

Herbivore enamel carbon isotopic composition and the environmental context of Ardipithecus at Gona, Ethiopia

Geol. Soc. Am. Spec. Pap., 446 (2008), pp. 215-234

Levin et al., 2015

N.E. Levin, Y. Haile-Selassie, S.R. Frost, B.Z. Saylor

Dietary change among hominins and cercopithecids in Ethiopia during the early Pliocene Proc. Natl. Acad. Sci., 112 (2015), pp. 12304-12309

Li et al., 2017

D. Li, C. Hu, W. Wang, J. Chen, F. Tian, S. Huang, C.J. Bae

The stable isotope record in cervid tooth enamel from Tantang cave, Guangxi: implications for the Quaternary East Asian monsoon

Quat. Int., 434 (2017), pp. 156-162

ArticleDownload PDFCrossRefView Record in ScopusGoogle Scholar

Liu et al., 2010a

W. Liu, C.-Z. Jin, Y.-Q. Zhang, Y.-J. Cai, S. Xing, X-j. Wu, H. Cheng, R.L. Edwards, W.-S. Pan, D.-G. Qin, Z.-S. An, E. Trinkaus, X.-Z. Wu

Human remains from Zhirendong, south China, and modern human emergence in East Asia Proc. Natl. Acad. Sci., 107 (2010), pp. 19201-19206 
Liu et al., 2010b

W. Liu, X. Wu, S. Pei, X. Wu, C.J. Norton

Huanglong Cave: a Late Pleistocene human fossil site in Hubei Province, China

Quat. Int., 211 (2010), pp. 29-41

Liu et al., 2015

W. Liu, M. Martinón-Torres, Y-j. Cai, S. Xing, H-w. Tong, S-w. Pei, J.M. Sier, X-h. Wu, L. Edwards, H. Cheng, Y-y. Li, X-x. Yang, J.M. Bermúdez de Castro, X-j. Wu

The earliest unequivocally modern humans in southern China

Nature, 526 (2015), pp. 696-700

Longinelli, 1984

A. Longinelli

Oxygen isotopes in mammal bone phosphate: a new tool for paleohydrological and paleoclimatological research?

Geochim. Cosmochim. Acta, 48 (1984), pp. 385-390

Luz et al., 1984

B. Luz, Y. Kolodny, M. Horowitz

Fractionation of oxygen isotopes between mammalian bone-phosphate and environmental drinking water

Geochim. Cosmochim. Acta, 48 (1984), pp. 1689-1693

Ma et al., 2017

J. Ma, Y. Wang, C. Jin, Y. Yan, Y. Qu, Y. Hu

Isotopic evidence of foraging ecology of Asian elephant (Elephas maximus) in South China during the Late Pleistocene

Quat. Int., 443 (2017), pp. 160-167

McBrearty and Brooks, 2000

S. McBrearty, A. Brooks 
The revolution that wasn't: a new interpretation of the origin of modern human behavior J. Hum. Evol., 39 (2000), pp. 453-563

McCarroll and Loader, 2006

D. McCarroll, N.J. Loader

Isotopes in tree rings

Isotopes in Palaeoenvironmental Research, Springer Netherlands (2006), pp. 67-116

Medina et al., 1986

E. Medina, G. Montes, E. Cuevas, Z. Rokzandic

Profiles of $\mathrm{CO}_{2}$ concentration and $\delta^{13} \mathrm{C}$ values in tropical rain forests of the upper Rio Negro Basin, Venezuela

J. Trop. Ecol., 2 (1986), pp. 207-217

Mellars, 2006a

P. Mellars

Going east: new genetic and archaeological perspectives on the modern human colonization of Eurasia

Science, 313 (2006), pp. 796-800

Mellars, 2006b

P. Mellars

Why did modern human populations disperse from Africa ca. 60,000 years ago? A new model Proc. Natl. Acad. Sci. U. S. A., 103 (2006), pp. 9381-9386

Mellars et al., 2013

P. Mellars, K.C. Gori, M. Carr, P.A. Soares, M.B. Richards

Genetic and archaeological perspectives on the initial modern human colonization of southern Asia

Proc. Natl. Acad. Sci., 110 (2013), pp. 10699-10704 
Michel et al., 2016

V. Michel, H. Valladas, G. Shen, W. Wang, J-x. Zhao, C.-C. Shen, P. Valensi, C.J. Bae

The earliest modern Homo sapiens in China?

J. Hum. Evol., 101 (2016), pp. 101-104

Mijares et al., 2010

A.S. Mijares, F. Détroit, P. Piper, R. Grün, P. Bellwood, M. Aubert, G. Champion, N. Cuevas, A. De Leon, E. Dizon

New evidence for a 67,000-year-old human presence at Callao Cave, Luzon, Philippines

J. Hum. Evol., 59 (2010), pp. 123-132

Morley, 2017

M.W. Morley

The geoarchaeology of hominin dispersals to and from tropical Southeast Asia: a review of prognosis

J. Archaeol. Sci., 77 (2017), pp. 78-93

Norton and Jin, 2009

C.J. Norton, J.H.N. Jin

The evolution of modern human behavior in East Asia: current perspectives

Evol. Anthropol., 18 (2009), pp. 247-260

Nowak, 1999

R.M. Nowak

Walker's Mammals of the World. Sixth Edition. Volume I

The Johns Hopkins University Press, Baltimore and London (1999)

(1999, 836 pp.)

O'Leary, 1981

M.H. O'Leary 
Carbon isotope fractionation in plants

Phytochemistry, 20 (1981), pp. 553-567

O'Leary, 1988

M.H. O'Leary

Carbon isotopes in photosynthesis

Bioscience, 38 (1988), pp. 328-336

Olsen and Ciochon, 1990

J.W. Olsen, R.L. Ciochon

A review of evidence for postulated Middle Pleistocene occupations in Viet Nam

J. Hum. Evol., 19 (1990), pp. 761-788

Ometto et al., 2005

J.P.H. Ometto, L.B. Flanagan, L.A. Martinelli, J.R. Ehleringer

Oxygen isotope ratios of waters and respired $\mathrm{CO}_{2}$ in Amazonian forest and pasture ecosystems Ecol. Appl., 15 (2005), pp. 58-70

Oppenheimer, 2012

S. Oppenheimer

A single southern exit of modern humans from Africa: before or after Toba?

Quat. Int., 258 (2012), pp. 88-89

Owen-Smith, 1988

R.N. Owen-Smith

Megaherbivores. The Influence of Very Large Body Size on Ecology

Cambridge University Press (1988)

Passey et al., 2005 
B.H. Passey, T.F. Robinson, L.K. Ayliffe, T.E. Cerling, M. Sponheimer, M.D. Dearing, B.L. Roeder, J.R. Ehleringer

Carbon isotope fractionation between diet, breath $\mathrm{CO} 2$, and bioapatite in different mammals J. Archaeol. Sci., 32 (2005), pp. 1459-1470

Perera et al., 2011

N. Perera, N. Kourampas, I.A. Simpson, S.U. Deraniyagala, D. Bulbeck, J. Kamminga, J. Perera, D.Q. Fuller, K. Szabó, N.V. Oliveira

People of the ancient rainforest: Late Pleistocene foragers at the Batadomba-Iena rockshelter, Sri Lanka

J. Hum. Evol., 61 (2011), pp. 254-269

Petraglia et al., 2007

M. Petraglia, R. Korisettar, N. Boivin, C. Clarkson, P. Ditchfield, S. Jones, J. Koshy, et al.

Middle Paleolithic assemblages from the Indian subcontinent before and after the Toba supereruption

Science, 317 (2007), pp. 114-116

Petraglia et al., 2012

M. Petraglia, P. Ditchfield, S. Jones, R. Korisettar, J.N. Pal

The Toba volcanic super-eruption, environmental change, and hominin occupation history in India over the past 140,000 years

Quat. Int., 258 (2012), pp. 119-134

Piper and Rabett, 2009

P.J. Piper, R.J. Rabett

Hunting in a tropical rainforest: evidence from the terminal Pleistocene at Lobang Hangus, Niah caves, Sarawak

Int. J. Osteoarchaeol., 19 (2009), pp. 551-565

Prentice et al., 1992 
I.C. Prentice, W. Cramer, S.P. Harrison, R. Leemans, R.A. Monserud, A.M. Solomon

A global biome model based on plant physiology and dominance, soil properties and climate J. Biogeogr., 19 (1992), pp. 117-134

Pushkina et al., 2010

D. Pushkina, H. Bocherens, Y. Chaimanee, J.J. Jaeger

Stable carbon isotope reconstructions of diet and paleoenvironment from the late Middle Pleistocene Snake Cave in Northeastern Thailand

Naturwissenschaften, 97 (2010), pp. 299-309

Rabett, 2018

R.J. Rabett

The success of failed Homo sapiens dispersals out of Africa and into Asia Nat. Ecol. Evol., 2 (2018), pp. 212-219

Ramesh et al., 2012

T. Ramesh, K. Sankar, Q. Qureshi, R. Kalle

Group size, sex and age composition of chital (Axis axis) and sambar (Rusa unicolor) in a deciduous habitat of western Ghats

Mamm. Biol., 77 (2012), pp. 53-59

Reyes-Centeno, 2016

H. Reyes-Centeno

Out of Africa and into Asia: fossil and genetic evidence on modern human origins and dispersals Quat. Int., 416 (2016), pp. 249-262

Rink et al., 2008

W.J. Rink, W. Wei, D. Bekken, H.L. Jones

Geochronology of Ailuropoda-Stegodon fauna and Gigantopithecus in Guangxi Province, southern China 
Quat. Res., 69 (2008), pp. 377-387

Roberts et al., 2015

P. Roberts, N. Perera, O. Wedage, S. Deraniyagala, J. Perera, S. Eregama, A. Gledhill, M.D.

Petraglia, J.A. Lee-Thorp

Direct evidence for human reliance on rainforest resources in late Pleistocene Sri Lanka Science, 347 (2015), pp. 1246-1249

Roberts et al., 2017a

P. Roberts, N. Perera, O. Wedage, S. Deraniyagala, J. Perera, S. Eregama, M.D. Petraglia, J.A. Lee-Thorp

Fruits of the forest: human stable isotope ecology and rainforest adaptations in Late Pleistocene and Holocene ( 36 to $3 \mathrm{ka}$ ) Sri Lanka J. Hum. Evol., 106 (2017), pp. 102-118

Roberts et al., 2017b

P. Roberts, S.A. Blumenthal, W. Dittus, O. Wedage, J.A. Lee-Thorp

Stable carbon, oxygen, and nitrogen, isotope analysis of plants from a South Asian tropical forest: implications for primatology

Am. J. Primatol., 79 (2017)

Sage et al., 1999

R.F. Sage, D.A. Wedin, M. Li

The biogeography of $\mathrm{C} 4$ photosynthesis: patterns and controlling factors

C4 Plant Biology, Academic Press (1999), pp. 313-373

Schaller, 1967

G.B. Schaller

The Deer and the Tiger

University of Chicago Press, Chicago (1967) 
Schepartz and Miller-Antonio, 2010

L.A. Schepartz, S. Miller-Antonio

Large mammal exploitation in Late Middle Pleistocene China: a comparison of rhinoceros and stegodonts at Panxian Dadong

Before Farming, 4 (2010), pp. 1-14

Shackelford et al., 2018

L. Shackelford, F. Demeter, K. Westaway, P. Duringer, J.-L. Ponche, T. Sayavongkhamdy, Zhao J-x, L. Barnes, M. Boyon, S. Sichanthongtip, F. Sénégas, E. Patole-Edoumba, Y. Coppens, J.

Dumoncel, A.-M. Bacon

Additional evidence for early modern human morphological diversity in Southeast Asia at Tam Pa Ling, Laos

Quat. Int., 466 (2018), pp. 93-106

Shen et al., 2013

G. Shen, X. Wu, Q. Wang, H. Tu, Y.-x. Feng, J.-x. Zhao

Mass spectrometric U-series dating of Huanglong Cave in Hubei Province, central China:

evidence for early presence of modern humans in eastern Asia

J. Hum. Evol., 65 (2013), pp. 162-167

Smith and Epstein, 1971

B.N. Smith, S. Epstein

Two categories of ${ }^{13} \mathrm{C} /{ }^{12} \mathrm{C}$ ratios for higher plants 1

Plant Physiol., 47 (1971), pp. 380-384

Sponheimer and Lee-Thorp, 1999

M. Sponheimer, J.A. Lee-Thorp

Oxygen isotopes in enamel carbonate and their ecological significance

J. Archaeol. Sci., 26 (1999), pp. 723-728

Sponheimer et al., 2003 
M. Sponheimer, T. Robinson, L. Ayliffe, B. Passey, B. Roeder, L. Shipley, E. Lopez, T. Cerling, D. Dearing, J. Ehleringer

An experimental study of carbon-isotope fractionation between diet, hair, and feces of mammalian herbivores

Can. J. Zool., 81 (5) (2003), pp. 871-876

Sponheimer et al., 2006

M. Sponheimer, J.E. Loudon, D. Codron, M.E. Howells, J.D. Pruetz, J. Codron, D.J. de Ruiter, J.A. Lee-Thorp

Do "savanna" chimpanzees consume $\mathrm{C} 4$ resources?

J. Hum. Evol., 51 (2006), pp. 128-133

Sponheimer et al., 2013

M. Sponheimer, Z. Alemseged, T.E. Cerling, F.E. Grine, W.H. Kimbel, M.G. Leakey, J.A. LeeThorp, et al.

Isotopic evidence of early hominin diets

Proc. Natl. Acad. Sci., 110 (2013), pp. 10513-10518

Stacklyn, 2016

S.K. Stacklyn

Stable Isotopic Evidence for Diets and Niche Differentiation of Early Pleistocene Panda and Associated Mammals From Yanliang Cave, South China

The Florida State University (2016)

(Doctoral dissertation)

Stacklyn et al., 2017

S. Stacklyn, Y. Wang, C.Z. Jin, Y. Wang, F. Sun, C. Zhang, S. Jiang, T. Deng

Carbon and oxygen isotopic evidence for diets, environments and niche differentiation of early Pleistocene pandas and associated mammals in South China

Palaeogeogr. Palaeoclimatol. Palaeoecol., 468 (2017), pp. 351-361 
Steele, 2003

T.E. Steele

Using mortality profiles to infer behavior in the fossil record

J. Mammal., 84 (2003), pp. 418-430

Sternberg et al., 1989

L.S.L. Sternberg, S.S. Mulkey, S.J. Wright

Oxygen isotope ratio stratification in a tropical moist forest

Oecologia, 81 (1989), pp. 51-56

Still et al., 2003

C.J. Still, J.A. Berry, G.J. Collatz, R.S. DeFries

Global distribution of $\mathrm{C}_{3}$ and $\mathrm{C}_{4}$ vegetation: carbon cycle implications

Glob. Biogeochem. Cycles, 17 (1) (2003), p. 1006, 10.1029/2001GB001807

(2003)

Storm and de Vos, 2006

P. Storm, J. de Vos

Rediscovery of the Late Pleistocene Punung hominin sites and the discovery of a new site Gunung Dawung in East Java

Senckenb. Lethaea, 86 (2) (2006), pp. 121-131

Storm et al., 2005

P. Storm, F. Aziz, J. de Vos, D. Kosasih, S. Baskoro, Ngaliman, L.W. van den Hoek Ostende

Late Pleistocene Homo sapiens in a tropical rainforest fauna in East Java

J. Hum. Evol., 49 (2005), pp. 536-545

Sutikna et al., 2016 
T. Sutikna, M.W. Tocheri, M.J. Morwood, E.W. Saptomo, Jatmiko, R. Due Awe, S. Wasisto, K.E. Westaway, M. Aubert, B. Li, J.X. Zhao, M. Storey, B.V. Alloway, M.W. Morley, J.M. Hanneke, G.D. van den Bergh, R. Grün, A. Dosseto, A. Brumm, W.L. Jungers, R.G. Roberts

Revised stratigraphy and chronology for Homo floresiensis at Liang Bua in Indonesia Nature, 532 (2016), pp. 366-369

Tieszen et al., 1997

L.L. Tieszen, B.C. Reed, N.B. Bliss, B.K. Wylie, D.D. DeJong

NDVI, $\mathrm{C}_{3}$ and $\mathrm{C}_{4}$ production, and distributions in Great Plains grassland land cover classes Ecol. Appl., 7 (1997), pp. 59-78

van der Merwe and Medina, 1989

N.J. van der Merwe, E. Medina

Photosynthesis and $13 \mathrm{C} 12 \mathrm{C}$ ratios in Amazonian rain forests

Geochim. Cosmochim. Acta, 53 (1989), pp. 1091-1094

van der Merwe and Medina, 1991

N.J. van der Merwe, E. Medina

The canopy effect, carbon isotope ratios and foodwebs in Amazonia

J. Archaeol. Sci., 18 (1991), pp. 249-259

Vogel, 1978

J.C. Vogel

Recycling of carbon in a forest environment

Oecologia Plantarum, 13 (1978), pp. 89-94

Wang et al., 2007

W. Wang, R. Potts, Y. Baoyin, W. Huang, H. Cheng, R.L. Edwards, P. Ditchfield

Sequence of mammalian fossils, including hominoid teeth, from the Bubing Basin caves, south China 
J. Hum. Evol., 52 (2007), pp. 370-379

Wang et al., 2008

Y. Wang, H. Cheng, L.R. Edwards, X. Kong, X. Shao, S. Chen, J. Wu, X. Jiang, X. Wang, Z. An

Millennial- and orbital-scale changes in the East Asian monsoon over the past 224,000 years

Nature, 451 (2008), pp. 1090-1093

Westaway et al., 2007

K.E. Westaway, M.J. Morwood, R.G. Roberts, A.D. Rokus, J.X. Zhao, P. Storm, F. Aziz, G. van den Bergh, P. Hadi, Jatmiko, J. de Vos

Age and biostratigraphic significance of the Punung rainforest fauna East Java, Indonesia, and implications for Pongo and Homo

J. Hum. Evol., 53 (2007), pp. 709-717

Westaway et al., 2017

K.E. Westaway, J. Louys, D. Due Awe, M.J. Morwood, G.J. Price, J-x. Zhao, M. Aubert, R.

Joannes-Boyau, T.M. Smith, M.M. Skinner, T. Compton, R.M. Bailey, G.D. van den Bergh, J. de Vos, A.W.G. Pike, C. Stringer, E.W. Saptomo, Y. Rizal, J. Zaim, W.D. Santoso, A. Trihascaryo, L. Kinsley, B. Sulisttyanto

An early modern human presence in Sumatra 73,000-63,000 years ago

Nature, 548 (2017), pp. 322-325

White et al., 2009

T.D. White, B. Asfaw, Y. Beyene, Y. Haile-Selassie, C.O. Lovejoy, G. Suwa, G. WoldeGabriel

Ardipithecus ramidus and the paleobiology of early hominids

Science, 326 (2009), pp. 64-86

Wu and Poirier, 1995

X.Z. Wu, F.E. Poirier

Human Evolution in China. A Metric Description of the Fossils and a Review of the Sites Oxford University Press, New York (1995) 
(317 pp.)

Yakir, 1992

D. Yakir

Variations in the natural abundance of oxygen-18 and deuterium in plant carbohydrates Plant Cell Environ., 15 (1992), pp. 1005-1020

Yokoyama et al., 2008

Y. Yokoyama, C. Falguères, F. Sémah, T. Jacob, R. Grün

Gamma-ray spectrometric dating of late Homo erectus skulls from Ngandong and Sambungmacan, Central Java, Indonesia

J. Hum. Evol., 55 (2008), pp. 274-277

Zheng and Lei, 1999

Z. Zheng, Z.-Q. Lei

A 400,000 year record of vegetational and climatic changes from a volcanic basin, Leizhou Peninsula, southern China 